\title{
Identification of yellowhorn (Xanthoceras sorbifolium) WRKY transcription factor family and analysis of abiotic stress response model
}

\author{
Zhi Liu $^{1,2}$ - Saiyinduleng ${ }^{3}$ Qiaoying Chang ${ }^{1,2}$. \\ Chuwen Cheng ${ }^{4} \cdot$ Zhimin Zheng $^{1} \cdot$ Song Yu ${ }^{1}$
}

Received: 24 December 2019 / Accepted: 18 February 2020 / Published online: 7 May 2020

(C) The Author(s) 2020

\begin{abstract}
WRKY transcription factors are widely distributed in higher plants and play important roles in many biological processes, including stress resistance. The recently published genome sequence of yellowhorn, an oil tree with robust resistance to cold, drought, heat, salt and alkali, provides an excellent opportunity to identify and characterize the entire yellowhorn WRKY protein family and a basis for the study of abiotic stress resistance of WRKY gene family in forest species. In the present comprehensive analysis of WRKY transcription factors in yellowhorn, 65 WRKY genes were identified and defined based on their location on the chromosome. According to their structure and phylogenetic relationships, $X s W R K Y$ genes clustered into WRKY groups I-III. Segmental duplication events played a significant
\end{abstract}

Zhi Liu and Saiyinduleng have contributed equally to this work.

Project funding: This work was supported by the Fundamental Research Funds for the Central Universities (2572017DA03) and Development and Identification of Molecular Markers for Fine Strains of Xanthoceras sorbifolia (MOMA-2019ZENITHGENE).

The online version is available at http://www.springerlink.com.

Corresponding editor: Tao Xu.

Electronic supplementary material The online version of this article (https://doi.org/10.1007/s11676-020-01134-6) contains supplementary material, which is available to authorized users.

Zhimin Zheng

zmzheng@nefu.edu.cn

Song Yu

yusong@nefu.edu.cn

1 State Key Laboratory of Tree Genetics and Breeding, School of Forestry, Northeast Forestry University, Harbin 150040, People's Republic of China role in the expansion of $W R K Y$ gene family. Furthermore, transcriptomic data and real-time quantitative PCR analysis showed that expression of $X s W R K Y$ genes responding to salt and drought stresses and a hormone treatment. We also determined structures of the encoded proteins, cis-elements of the promoter region, and expression patterns. These results provide a foundation for the study of the biological function of $W R K Y$ transcription factors in yellowhorn.

Keywords Yellowhorn (Xanthoceras sorbifolium) . WRKY transcription factor $\cdot$ Stress $\cdot$ ABA $\cdot$ Gene expression

\section{Introduction}

Transcription factors are proteins that bind specifically to gene promoter regions and thus regulate transcription and gene expression in response to internal and external stimuli. Unique to plants, the WRKY family is ubiquitous one of the largest transcription factor families in higher plants. WRKY transcription factors are major regulators of many plant biological processes, including abiotic and biotic stress responses, growth and development, carbohydrate synthesis, senescence and secondary metabolite synthesis (Eulgem et al. 2000; Robatzek and Somssich 2002; Sun et al. 2003; Wang et al. 2010a, b). WRKY transcription factors are

2 The College of Life Science, Northeast Forestry University, Harbin 150040, People's Republic of China

3 Kundu Forest Farm of Aluke'rqin Banner, Chifeng Academy of Forestry, Chifeng 024005, People's Republic of China

4 College of Bioscience and Biotechnology, Shenyang Agricultural University, Shenyang 110866, People's Republic of China 
defined by the conserved DNA binding domain (DBD) and the WRKY domain, which comprises approximately 60 residues, consisting of an N-terminal DNA binding domain and a zinc finger motif at the C-terminal (Eulgem et al. 2000). The DBD sequence is highly conserved, but the residues of the WRKY domain are sometimes replaced by WRRY, WKRY, WSKY, WVKY, or WKKY (Xie et al. 2005). The zinc finger motif of the $W R K Y$ family forms two modes during evolution: $\mathrm{C} 2 \mathrm{H} 2$ (C-X4-5-C-X22-23-H-X1-H) and C2HC (C-X7-C-X23-H-X-C) (Eulgem et al. 2000). According to the amino acid sequences, WRKY transcription factors can be divided into three groups (Eulgem et al. 2000; Zhang and Wang 2005; Rushton et al. 2010, 2012). The first group of WRKY proteins have two DBD domains and one $\mathrm{C} 2-\mathrm{H} 2$ zinc finger motif (C-X4-5-C-X22-23-H-X1-H), the second and third groups have only one DBD domain and a zinc finger motif. However, the zinc finger motifs in the second group are C-X4-5-C-X22-23-H-X1-H (Kumar et al. 2016; Gu et al. 2018a, b) and in the third group, C2-HC (C-X7-C-X23-H-X1-C) (Kumar et al. 2016; Gu et al. 2018a, b). In addition to the WRKY domain and zinc finger motif, some WRKY transcription factors also contain other structures, such as nuclear localization signal, leucine zipper, glutamic acid enrichment region, proline-rich region and kinase domain (Tian et al. 2006; Agarwal et al. 2011).

Numerous studies have shown that WRKY transcription factors are involved in plant responses to various biotic and abiotic stresses (Rushton et al. 2012; Wang et al. 2014, 2016). In Arabidopsis thaliana, AtWRKY22 and AtWRKY29 are induced as part of a defense response to an elicitor from a bacterial plant pathogen, perhaps through activation of a mitogen-activated protein kinase (MAPK) cascade or calcium-dependent protein kinase (CDPK) (Göhre et al. 2012), while overexpression of AtWRKY38 and AtWRKY62 in double mutants of A. thaliana reduces disease resistance (Kim et al. 2008). AtWRKY48 gain-of-function transgenic overexpression mutants had impaired resistance to the bacterial pathogen Pseudomonas syringae and lossof-function T-DNA insertion mutants had enhanced resistance associated with increased of a salicylic acid-regulated defense-related protein (PR1) (Xing et al. 2008). Similarly, $W R K Y$ genes such as BdWRKY8, BdWRKY34, BdWRKY50, $B d W R K Y 69$, and $B d W R K Y 70$ in barley were upregulated after inoculation with Fusarium graminearum, causal fungus of Fusarium head blight. It can cause diseases such as ear rot, stem rot, stem base rot and root rot, and can also infect other plants (Wen et al. 2014). Studies have also shown that various plants overexpressing $W R K Y$ genes had strong resistance to salt stress (e.g., TaWRKY10 in wheat (Wang et al. 2013) ZmWRKY23 in Zea mays, (Jiang and Yu 2009); OsWRKY45 and OsWRKY72 in Oryza sativa (Yu et al. 2010; Uji et al. 2019). WRKY transcription factors are also essential in signaling pathways mediated by salicylic acid (SA) and by abscisic acid (ABA) (Qiu and Yu 2009) and in plant growth and development. AtWRKY6, AtWRKY22 (Zhou et al. 2011; Zhang et al. 2018), AtWRKY57 (Jiang et al. 2014), AtWRKY53 (Miao et al. 2013), AtWRKY54 and AtWRKY70 (Besseau et al. 2012) are involved in the regulation of senescence. Also, WRKY transcription factors regulate the synthesis of the secondary metabolites, including terpenes, lignin, flavanol, kaempferol, and quercetin (Yokotani et al. 2013).

In addition to the study of the WRKY gene family in model species, studies on WRKY transcription factors in tree species have indicated that Populus euphratica the formation of new WRKY family members and adaptive evolution of other genes may have played an important role in the evolution of high salt tolerance in this species (Ma et al. 2015). EgWRKY18 and EgWRKY64 in Elaeis guineensis are conducive to improving their cold resistance, while the induced expression of $E g W R K Y 07$ and $E g W R K Y 52$ is beneficial to resistance to salt stress (Xiao et al. 2017). SaWRKYI is involved in SA and MeJA-mediated abiotic or biological response pathways, and its overexpression improves the salt tolerance of transgenic A. thaliana (Yan et al. 2019).

So far, the studies of WRKY transcription factors have mainly focused on model plants or horticultural plants that are sensitive to stress. So studies of WRKY transcription factors in the stress-tolerant plants will help us to understand the molecular mechanism of the WRKY transcription factors in the processes of stress resistance. Yellowhorn (Xanthoceras sorbifolium) has robust resistance to low temperature, drought, heat, salt and alkali stresses, and it also has high potential for use an edible oil and biofuel because of the high oil content in its seeds. Making use of the recently sequenced yellowhorn genome (Bi et al. 2019), we here identified 56 $W R K Y$ genes in the yellowhorn genome and explored their composition, gene structure and gene replication events. Using transcriptomic data for yellowhorn, we also identified some $W R K Y$ genes that respond to various stresses such as $\mathrm{NaCl}$, cold and ABA since WRKY genes have been reported to play a vital role in regulating plant tolerance to $\mathrm{NaCl}$ and cold stress and in regulating ABA signaling (Wang et al. 2014; Yan et al. 2014; Zhang et al. 2016).

\section{Materials and methods}

\section{Genome-wide identification of WRKY genes in yellowhorn}

The genomic and protein sequences of yellowhorn and annotated gene models were obtained from the Yellowhorn Genome Project of the Institute of Beijing Academy of Forestry Sciences (Bi et al. 2019). WRKY family of proteins from A. thaliana, O. sativa, Malus domestica, $Z$. 
mays, and Glycine max was downloaded from the plant TFDB (https://planttfdb.cbi.pku.edu.cn) (Jin et al. 2017), and BLASTP was used to search for homologous WRKY genes. The targeted genes (E-value less than 1e-5) were retained for the following analysis. The WRKY domain (PF03106) from Pfam (https://pfam.xfam.org/) (El-Gebali et al. 2019) and WRKY gene were subsequently identified from among the genes of the yellowhorn genome using HMMER 3.1 (Mistry et al. 2013). The target gene was screened according to e-value $<1.0$, and the integrity of the WRKY domain (e-value $<0.1$ ) was further confirmed using the online software SMART (https:// smart.embl-heidelberg.de/) (Letunic and Bork 2018) and National Center of Biotechnology Information CDsearch (https://www.ncbi.nlm.nih.gov/Structure/cdd/wrpsb .cgi) (Marchler-Bauer et al. 2017). Finally, the repetitive sequence and the incomplete sequence were manually removed, and the confirmed gene was designated as the yellowhorn $W R K Y$ gene family. The isoelectric point of the XsWRKY protein was identified using the ExPasy online website (https://web.expasy.org/protparam/) (Gasteiger et al. 2003). MEGA6 (Tamura et al. 2013) software was used for multiple sequence alignment analysis of the WRKY domain. The subcellular localization of XsWRKY in yellowhorn was predicted using the subcellular localization online prediction tool MBC (https://cello.life.nctu. edu.tw/) (Yu et al. 2006).

\section{Phylogenetic analyses of the WRKY proteins}

Yellowhorn phylogenetic tree was constructed from the WRKY domain and amino acid sequence of A. thaliana using the maximum likelihood (ML) MEGA6 (Tamura et al. 2013), and the bootstrap test was set as 1,000 replications. Visualization and beautification of the phylogenetic tree were used iTOL (https://itol.embl.de/) (Letunic and Bork 2019).

\section{Gene structure of WRKY genes}

Information on the structure of $W R K Y$ genes was extracted from the general feature format file of the yellowhorn genome. The TBtools platform (https://github.com/CJ-Chen/ TBtools) (Chen et al. 2018) was used to display the exon/ intron structures, conservative motifs, and WRKY domain of each predicted XsWRKY gene, and meme (https://meme. nbcr.net/meme/intro.html) (Bailey et al. 2009) was used to identify other conserved motifs (Motif number was set to 20; the rest were the full-length protein using default settings.) in sequences of WRKY family members. The WRKY domain was annotated by the Pfam database (https://pfam.xfam.org/) (El-Gebali et al. 2019).

\section{Promoter analysis}

For this study, the 2-kb upstream sequence of the coding region of the WRKY genes was scanned using PlantCARE (https://bioinformatics.psb.ugent.be/webtools/plantcare/ $\mathrm{html} /)$ (Lescot et al. 2002) to identify transcription factor binding sites. Low temperature, defense responses, hormone responses, drought responses, heat stress, and salt response motif were selected for analysis of promoter specificity for abiotic stress response. TBtools (Chen et al. 2018) was used for visual display.

\section{Chromosome localization and synteny analysis}

BLASTP was used for all-against-all comparison (e-value: 1e-5) for information on gene pairs. Next, MCScan (https ://chibba.agtec.uga.edu/duplication/mcscan) (Wang et al. 2012) was adopted to analyze syntenic blocks and gene duplication events (using default settings) using gene pairs and gff files. Tandem duplications of $W R K Y$ genes were used to estimate nonsynonymous (Ka) and synonymous $(\mathrm{Ks})$ and calculate their ratio in KaKs_Calculator 2.0 (Wang et al. 2010a, b). Circos (Krzywinski et al. 2009) was used to draw a circular map of the yellowhorn genome according to gene position and genome collinearity information in the gff file.

\section{Plant materials and treatments}

Yellowhorn seedlings (4-weeks-old) were grown in vermiculite-humus $(1: 3)$ soil in a growth chamber at $22-24{ }^{\circ} \mathrm{C}, 60 \%$ relative humidity, and $12 \mathrm{~h} / 12 \mathrm{~h}$ photoperiod for 28 days as a non-stress treatment. Seedlings for stress treatments were grown similarly, with the following differences. For the salt treatment, plants were watered with $150 \mathrm{mM} \mathrm{NaCl}$. For ABA, $100 \mu \mathrm{M}$ was sprayed through the foliage. Coldstressed plants were grown at $4{ }^{\circ} \mathrm{C}$ in a growth chamber. For each treatment, three plants were sampled (biological repeats) with three corresponding untreated controls, and leaves were collected at 3, 6, 9, 12, 24, 48 and $72 \mathrm{~h}$. All leaf samples were immediately frozen in liquid nitrogen and stored at $-80^{\circ} \mathrm{C}$ until analyzed.

\section{Transcriptomics analysis}

The expression pattern of stress-related $W R K Y$ genes in yellowhorn after treatment with $150 \mathrm{mM} \mathrm{NaCl}, 4{ }^{\circ} \mathrm{C}$, or $100 \mathrm{mM}$ ABA for $24 \mathrm{~h}$ and $48 \mathrm{~h}$ was analyzed using RNAseq analysis of transcriptome data in the laboratory (unpublished). The program rnacocktail (Sahraeian et al. 2017) by Salmon was used to calculate the expression level TPM 
(per million transcripts), and DESeq2 (Love et al. 2014) was used to analyze differential expression of genes between the control with treatment groups and calculate the fold-change (FDR $\leq 0.05$, fold change $\geq 2$ ). A heatmap was constructed using the TBtools according to the expression matrix of $X s W R K Y$.

\section{Quantitative RT-PCR analysis}

The total RNA of yellowhorn was extracted using the OminiPlant RNA kit (DNase I) (CWBIO, Beijing, China). RNA quality and concentration was determined using agarose gel electrophoresis and a DHS NanoPro 2010 spectrophotometer (Ding Haoyuan, Beijing, China). Template cDNA was synthesized using $500 \mathrm{ng}$ of high-quality total RNA and the TaKaRa PrimeScriptTM RT Reagent Kit with gDNA Eraser (Perfect Real Time) (TaKaRa, Dalian, China) according to the manufacturer's instructions. Quantitative real-time PCR (qRT-PCR) primers were designed according to the CDS sequence of $X s W R K Y$ by Primer 5 software (Table S1), and primer mass was tested using PCR amplification, agarose gel electrophoresis, and melting curve analysis. qRT-PCR was performed using a Bio-Rad/CFX Connect real-time PCR detection system and UltraSYBR mixture (CWBIO, Beijing, China). Relative expression level of the XsWRKY gene was analyzed by the $2^{-\Delta \Delta \mathrm{Ct}}$ method and normalized to the average transcript amount of the XsACTIN gene (EVM0013888.1). The qRT-PCR experiments were done three times.

\section{Results}

\section{Identification of WRKY proteins in yellowhorn}

In this systematic analysis to identify WRKY proteins in yellowhorn, 67 potential WRKY proteins were identified using BLAST (Mount 2007) and HMMER (Mistry et al. 2013) for protein domain analysis. Two of these 67 (EVM0005841.1, EVM0022387.1) did not contain the complete amino acid sequence of the WRKY domain and were removed from the list. The remaining $65 W R K Y$ genes in the yellowhorn genome (Table 1) were denoted as XsWRKY1 through $X s W R K Y 59$ (Redundant protein numbers such as XsWRKY38, XsWRKY38.1, XsWRKY38.2, and XsWRKY38.3, are four genes with the same protein sequence and were sorted according to the order of genes on the chromosome.) based on their order on the chromosome, but four protein lines not mapped on the chromosome were classified by their number of contigs.

The length of the amino acid sequence in XsWRKY proteins ranged from 122 (XsWRKY24) to 759 (XsWRKY46), with an average length of 372 residues. The molecular weight (MW) of XsWRKY proteins ranged from $14.81 \mathrm{kDa}$ (XsWRKY24) to $83.18 \mathrm{kDa}$ (XsWRKY46), and the isoelectric point (pI) of the XsWKRY proteins ranged from 4.98 (XsWRKY42) to 9.78 (XsWRKY39), with 35 XsWRKYs having a $\mathrm{pI}<7$ and the rest having $\mathrm{pI}>7$ (Table 1). Transcription factors are usually localized in nucleus and bind to the target's promoter regions. Using the prediction tool, we found that all XsWRKYs were localized in the nucleus, except for XsWRKY14, which is expected to be localized in the plasma membrane (Table 1).

\section{Phylogenetic analysis of the XsWRKY family}

In the phylogenetic analysis of XsWRKY transcription factors using multiple sequence alignment of the 60-aa WRKY domain of XsWRKY protein, the WRKY domain from each WRKY transcription family and subfamily in A. thaliana, Populus trichocarpa, Z. mays was randomly selected as a representative of each family and aligned with that of XsWRKY. In yellowhorn, we found that 61 XsWRKY proteins have the full conserved sequence WRKYGQK, while the other XsWRKY proteins (XsWRKY15, XsWRKY16, XsWRKY21, XsWRKY36) are WRKYGKK (Fig. 1). Subsequently, in a preliminary classification based on the structure of the XsWRKY protein, 12 XsWRKY proteins with two WRKY domains and a C2H2-type zinc finger motif (C-X4-C-X22-23-HXH) were classified into group I. Among the remaining $53 \mathrm{XsWRKY}$ proteins, $45 \mathrm{XsWRKY}$ proteins having $\mathrm{C} 2 \mathrm{H} 2$-type zinc finger motif were classified as group II, and eight XsWRKY proteins containing the C2HC-type zinc finger were classified into group III (Fig. 1).

To further classify XsWRKY family members, three WRKY domains of each family and subfamily from A. thaliana, $P$. trichocarpa, and Z. mays were randomly selected to construct a phylogenetic tree together with the XsWRKY domain (Fig. 2). The phylogenetic tree shows that the WRKY domain of the second group can be divided into five subgroups (IIa-IIe). The C2H2-type zinc finger motif of $\mathrm{IIa}$, IIb, IId, IIe is C-X5-C-X23-HXH. However, the C2H2type zinc finger motif of $16 \mathrm{XsWRKY}$ in IIc is C-X4-C$\mathrm{X} 23-\mathrm{HXH}$, and the remaining two are C-X4-C-X16-HXH (Fig. 2).

\section{Gene structure of yellowhorn WRKY gene family and motif composition of WRKY proteins}

To further understand the gene structure and motif composition of the yellowhorn WRKY transcription factors, we further analyzed the gene structure of XsWRKY by using MEME. Twenty motifs were predicted in XsWRKY, and the details for the 20 conserved motifs are shown in the supplementary file (Fig. 3, Table S2). The length of motifs is approximate 10 amino acids to 50 amino acids, and each 
Table 1 List of the $65 X s W R K Y$ genes identified in this study

\begin{tabular}{|c|c|c|c|c|c|c|c|c|c|}
\hline WRKY ID & Gene ID & PI & WM & $\begin{array}{l}\text { Subcellular } \\
\text { localization }\end{array}$ & Domain & No. of aa & ORF length (bp) & Chromosome no & Group \\
\hline XsWRKY1 & EVM0000134.1 & 5.71 & $54,686.71$ & Nuclear & $\begin{array}{l}\text { WRKY } 1 \mathrm{C} 2 \mathrm{H} 2 \\
1\end{array}$ & 499 & 1500 & LG1 & IIc \\
\hline XsWRKY2 & EVM0005353.1 & 5.32 & $18,451.12$ & Nuclear & $\begin{array}{l}\text { WRKY } 1 \text { C } 2 \mathrm{H} 2 \\
1\end{array}$ & 160 & 483 & LG1 & IIc \\
\hline XsWRKY3 & EVM0001821.1 & 6.61 & $35,239.82$ & Nuclear & $\begin{array}{l}\text { WRKY } 1 \text { C } 2 \mathrm{H} 2 \\
1\end{array}$ & 322 & 969 & LG1 & IIe \\
\hline XsWRKY4 & EVM0020675.1 & 5.71 & $39,259.25$ & Nuclear & $\begin{array}{l}\text { WRKY } 1 \mathrm{C} 2 \mathrm{H} 2 \\
1\end{array}$ & 350 & 1053 & LG1 & IIc \\
\hline XsWRKY4.1 & EVM0020675.1 & 5.71 & $39,259.25$ & Nuclear & $\begin{array}{l}\text { WRKY } 1 \mathrm{C} 2 \mathrm{H} 2 \\
1\end{array}$ & 350 & 1053 & $\operatorname{ctg} 1541$ & IIc \\
\hline XsWRKY5 & EVM0007069.1 & 6.19 & $33,986.29$ & Nuclear & $\begin{array}{l}\text { WRKY } 1 \text { C2H } 2 \\
1\end{array}$ & 306 & 921 & LG1 & IIb \\
\hline XsWRKY6 & EVM0003466.1 & 8.45 & $38,425.92$ & Nuclear & $\begin{array}{l}\text { WRKY } 1 \mathrm{C} 2 \mathrm{CH} \\
1\end{array}$ & 344 & 1035 & LG1 & III \\
\hline XsWRKY7 & EVM0022523.1 & 8.76 & $37,776.86$ & Nuclear & $\begin{array}{l}\text { WRKY } 1 \text { C2H2 } \\
1\end{array}$ & 338 & 1017 & LG1 & IIc \\
\hline XsWRKY8 & EVM0013898.1 & 5.77 & $40,402.79$ & Nuclear & $\begin{array}{l}\text { WRKY } 1 \text { C2H2 } \\
1\end{array}$ & 373 & 1122 & LG1 & IIe \\
\hline XsWRKY9 & EVM0021161.2 & 9.11 & $29,439.52$ & Nuclear & $\begin{array}{l}\text { WRKY } 1 \mathrm{C} 2 \mathrm{H} 2 \\
1\end{array}$ & 260 & 783 & LG1 & IId \\
\hline XsWRKY10 & EVM0019044.1 & 9.25 & $19,963.32$ & Nuclear & $\begin{array}{l}\text { WRKY } 1 \text { C2H } 2 \\
1\end{array}$ & 172 & 519 & LG1 & IIc \\
\hline XsWRKY10.1 & EVM0019044.1 & 9.25 & $19,963.32$ & Nuclear & $\begin{array}{l}\text { WRKY } 1 \text { C2H2 } \\
1\end{array}$ & 172 & 519 & LG1 & IIc \\
\hline XsWRKY11 & EVM0015874.1 & 9.49 & $17,911.28$ & Nuclear & $\begin{array}{l}\text { WRKY } 1 \text { C2H2 } \\
1\end{array}$ & 156 & 471 & LG1 & $\mathrm{IIb}$ \\
\hline XsWRKY12 & EVM0018786.1 & 6.31 & $41,371.66$ & Nuclear & $\begin{array}{l}\text { WRKY } 2 \text { C2H } 2 \\
2\end{array}$ & 371 & 1116 & LG1 & I \\
\hline XsWRKY12.1 & EVM0018786.1 & 6.31 & $41,371.66$ & Nuclear & $\begin{array}{l}\text { WRKY } 2 \text { C2H } 2 \\
2\end{array}$ & 371 & 1116 & $\operatorname{ctg} 2419$ & I \\
\hline XsWRKY13 & EVM0009795.1 & 8.43 & $55,897.2$ & Nuclear & $\begin{array}{l}\text { WRKY } 1 \text { C2H2 } \\
1\end{array}$ & 511 & 1536 & LG1 & IIc \\
\hline XsWRKY14 & EVM0006339.1 & 9.38 & $37,533.58$ & $\begin{array}{l}\text { Plasma mem- } \\
\text { brane }\end{array}$ & $\begin{array}{l}\text { WRKY } 1 \mathrm{C} 2 \mathrm{CH} \\
1\end{array}$ & 333 & 1002 & LG2 & III \\
\hline XsWRKY15 & EVM0016791.1 & 5.36 & $39,564.73$ & Nuclear & $\begin{array}{l}\text { WRKY } 1 \text { C2H2 } \\
1\end{array}$ & 354 & 1065 & LG2 & IIc \\
\hline XsWRKY16 & EVM0016046.1 & 8.14 & $37,425.33$ & Nuclear & $\begin{array}{l}\text { WRKY } 1 \text { C2H } 2 \\
1\end{array}$ & 339 & 1020 & LG2 & IIc \\
\hline XsWRKY17 & EVM0018382.1 & 9.13 & $33,114.21$ & Nuclear & $\begin{array}{l}\text { WRKY } 1 \text { C2H2 } \\
1\end{array}$ & 300 & 903 & LG2 & $\mathrm{IIb}$ \\
\hline XsWRKY18 & EVM0015392.1 & 8.83 & $14,886.81$ & Nuclear & $\begin{array}{l}\text { WRKY } 1 \text { C2H2 } \\
1\end{array}$ & 122 & 369 & LG3 & IIc \\
\hline XsWRKY19 & EVM0014416.1 & 6.65 & $59,836.26$ & Nuclear & $\begin{array}{l}\text { WRKY } 1 \text { C } 2 \mathrm{H} 2 \\
1\end{array}$ & 539 & 1620 & LG3 & IIa \\
\hline XsWRKY20 & EVM0009035.1 & 5.71 & $55,257.41$ & Nuclear & $\begin{array}{l}\text { WRKY } 1 \text { C2H } 2 \\
1\end{array}$ & 504 & 1515 & LG3 & IIa \\
\hline XsWRKY21 & EVM0022609.1 & 6.56 & $37,890.63$ & Nuclear & $\begin{array}{l}\text { WRKY } 1 \text { C2H } 2 \\
1\end{array}$ & 347 & 1044 & LG3 & IIc \\
\hline XsWRKY22 & EVM0013326.2 & 9.59 & $34,986.39$ & Nuclear & $\begin{array}{l}\text { WRKY } 1 \text { C2H } 2 \\
1\end{array}$ & 319 & 960 & LG4 & IId \\
\hline XsWRKY23 & EVM0012322.1 & 9.11 & $21,811.69$ & Nuclear & $\begin{array}{l}\text { WRKY } 1 \text { C } 2 \mathrm{H} 2 \\
1\end{array}$ & 191 & 576 & LG5 & IIe \\
\hline XsWRKY24 & EVM0005716.1 & 8.84 & $14,810.71$ & Nuclear & $\begin{array}{l}\text { WRKY } 1 \mathrm{C} 2 \mathrm{H} 2 \\
1\end{array}$ & 122 & 369 & LG5 & IIc \\
\hline
\end{tabular}


Table 1 (continued)

\begin{tabular}{|c|c|c|c|c|c|c|c|c|c|}
\hline WRKY ID & Gene ID & PI & WM & $\begin{array}{l}\text { Subcellular } \\
\text { localization }\end{array}$ & Domain & No. of aa & ORF length (bp) & Chromosome no & Group \\
\hline XsWRKY25 & EVM0013194.1 & 7.07 & $70,712.6$ & Nuclear & $\begin{array}{l}\text { WRKY } 1 \text { C2 } 2 \text { 2 } \\
1\end{array}$ & 649 & 1950 & LG5 & IIe \\
\hline XsWRKY26 & EVM0001816.1 & 6.99 & $68,769.07$ & Nuclear & $\begin{array}{l}\text { WRKY } 2 \text { C2H2 } \\
2\end{array}$ & 625 & 1878 & LG5 & I \\
\hline XsWRKY27 & EVM0004495.1 & 9.37 & $36,426.59$ & Nuclear & $\begin{array}{l}\text { WRKY } 1 \text { C2H2 } \\
1\end{array}$ & 324 & 975 & LG5 & $\mathrm{IIb}$ \\
\hline XsWRKY28 & EVM0020928.1 & 6.94 & $22,986.19$ & Nuclear & $\begin{array}{l}\text { WRKY } 2 \text { C } 2 \mathrm{H} 2 \\
2\end{array}$ & 201 & 606 & LG6 & I \\
\hline XsWRKY29 & EVM0009790.1 & 6.72 & $42,494.57$ & Nuclear & $\begin{array}{l}\text { WRKY } 1 \text { C2H2 } \\
1\end{array}$ & 383 & 1152 & LG6 & IId \\
\hline XsWRKY30 & EVM0004255.1 & 5.12 & $30,994.11$ & Nuclear & $\begin{array}{l}\text { WRKY } 1 \text { C2H2 } \\
1\end{array}$ & 269 & 810 & LG8 & IIc \\
\hline XsWRKY31 & EVM0020089.1 & 5.88 & $67,790.72$ & Nuclear & $\begin{array}{l}\text { WRKY } 2 \text { C2H } 2 \\
2\end{array}$ & 622 & 1869 & LG8 & I \\
\hline XsWRKY32 & EVM0021666.1 & 5.99 & $59,926.62$ & Nuclear & $\begin{array}{l}\text { WRKY } 1 \text { C2H } 2 \\
1\end{array}$ & 554 & 1665 & LG8 & $\mathrm{IIb}$ \\
\hline XsWRKY33 & EVM0003950.1 & 6.16 & $32,151.41$ & Nuclear & $\begin{array}{l}\text { WRKY } 1 \text { C2 } 2 \text { 2 } \\
1\end{array}$ & 293 & 882 & LG8 & IIc \\
\hline XsWRKY34 & EVM0009513.1 & 7.69 & $58,116.99$ & Nuclear & $\begin{array}{l}\text { WRKY } 2 \text { C2 } 2 \text { 2 } \\
\quad 2\end{array}$ & 534 & 1605 & LG9 & I \\
\hline XsWRKY35 & EVM0021601.1 & 5.72 & $54,197.23$ & Nuclear & $\begin{array}{l}\text { WRKY } 1 \text { C } 2 \mathrm{H} 2 \\
1\end{array}$ & 496 & 1491 & LG9 & IIa \\
\hline XsWRKY36 & EVM0015892.1 & 5.19 & $27,764.88$ & Nuclear & $\begin{array}{l}\text { WRKY } 1 \text { C2H } 2 \\
1\end{array}$ & 247 & 744 & LG10 & IIc \\
\hline XsWRKY37 & EVM0007134.1 & 7.24 & $65,102.88$ & Nuclear & $\begin{array}{l}\text { WRKY } 1 \text { C2 } 2 \text { 2 } \\
1\end{array}$ & 591 & 1776 & LG10 & IIc \\
\hline XsWRKY38 & EVM0009349.1 & 9.44 & $23,414.96$ & Nuclear & $\begin{array}{l}\text { WRKY } 1 \text { C2H } 2 \\
1\end{array}$ & 208 & 627 & LG10 & IId \\
\hline XsWRKY38.1 & EVM0009349.1 & 9.44 & $23,414.96$ & Nuclear & $\begin{array}{l}\text { WRKY } 1 \text { C2 } 2 \text { 2 } \\
1\end{array}$ & 208 & 627 & LG10 & IId \\
\hline XsWRKY38.2 & EVM0009349.1 & 9.44 & $23,414.96$ & Nuclear & $\begin{array}{l}\text { WRKY } 1 \text { C2 } 2 \text { 2 } \\
1\end{array}$ & 208 & 627 & $\operatorname{ctg} 2862$ & IId \\
\hline XsWRKY38.3 & EVM0009349.1 & 9.44 & $23,414.96$ & Nuclear & $\begin{array}{l}\text { WRKY } 1 \text { C2H2 } \\
1\end{array}$ & 208 & 627 & $\operatorname{ctg} 3040$ & IId \\
\hline XsWRKY39 & EVM0017381.1 & 9.78 & $39,603.94$ & Nuclear & $\begin{array}{l}\text { WRKY } 1 \text { C2H } 2 \\
1\end{array}$ & 355 & 1068 & LG11 & $\mathrm{IIb}$ \\
\hline XsWRKY40 & EVM0000723.1 & 9.65 & $38,220.38$ & Nuclear & $\begin{array}{l}\text { WRKY } 1 \text { C2 } 2 \text { 2 } \\
1\end{array}$ & 349 & 1050 & LG11 & IIe \\
\hline XsWRKY41 & EVM0002462.1 & 8.55 & $27,915.54$ & Nuclear & $\begin{array}{l}\text { WRKY } 1 \mathrm{C} 2 \mathrm{CH} \\
1\end{array}$ & 241 & 726 & LG11 & III \\
\hline XsWRKY42 & EVM0010266.1 & 4.98 & $35,380.09$ & Nuclear & $\begin{array}{l}\text { WRKY } 1 \text { C2H2 } \\
1\end{array}$ & 318 & 957 & LG11 & IId \\
\hline XsWRKY43 & EVM0006293.1 & 5.36 & $33,837.8$ & Nuclear & $\begin{array}{l}\text { WRKY } 1 \text { C2H } 2 \\
1\end{array}$ & 300 & 903 & LG12 & IIe \\
\hline XsWRKY44 & EVM0007056.1 & 6.52 & $61,996.35$ & Nuclear & $\begin{array}{l}\text { WRKY } 1 \mathrm{C} 2 \mathrm{CH} \\
1\end{array}$ & 569 & 1710 & LG12 & III \\
\hline XsWRKY45 & EVM0002590.1 & 9.74 & $39,138.46$ & Nuclear & $\begin{array}{l}\text { WRKY } 1 \mathrm{C} 2 \mathrm{CH} \\
1\end{array}$ & 348 & 1047 & LG13 & III \\
\hline XsWRKY46 & EVM0013857.1 & 5.38 & $83,179.43$ & Nuclear & $\begin{array}{l}\text { WRKY } 2 \text { C2H } 2 \\
2\end{array}$ & 759 & 2280 & LG13 & I \\
\hline XsWRKY47 & EVM0009650.1 & 5.84 & $46,304.85$ & Nuclear & $\begin{array}{l}\text { WRKY } 1 \text { C2H2 } \\
1\end{array}$ & 418 & 1257 & LG13 & $\mathrm{IIb}$ \\
\hline XsWRKY48 & EVM0022427.1 & 6.5 & $43,023.12$ & Nuclear & $\begin{array}{l}\text { WRKY } 2 \text { C2 } 2 \text { 2 } \\
2\end{array}$ & 392 & 1179 & LG13 & I \\
\hline
\end{tabular}


Table 1 (continued)

\begin{tabular}{|c|c|c|c|c|c|c|c|c|c|}
\hline WRKY ID & Gene ID & PI & WM & $\begin{array}{l}\text { Subcellular } \\
\text { localization }\end{array}$ & Domain & No. of aa & ORF length (bp) & Chromosome no & Group \\
\hline XsWRKY49 & EVM0014759.1 & 8.56 & $57,470.8$ & Nuclear & $\begin{array}{l}\text { WRKY } 1 \text { C2H2 } \\
1\end{array}$ & 526 & 1581 & LG13 & IIc \\
\hline XsWRKY50 & EVM0022939.2 & 5.18 & $27,804.9$ & Nuclear & $\begin{array}{l}\text { WRKY } 2 \text { C } 2 \mathrm{H} 2 \\
2\end{array}$ & 246 & 741 & LG13 & I \\
\hline XsWRKY51 & EVM0014166.1 & 7.76 & $25,870.39$ & Nuclear & $\begin{array}{l}\text { WRKY } 2 \text { C } 2 \mathrm{H} 2 \\
2\end{array}$ & 225 & 678 & LG14 & I \\
\hline XsWRKY52 & EVM0017304.1 & 6.03 & $66,351.1$ & Nuclear & $\begin{array}{l}\text { WRKY } 2 \text { C } 2 \mathrm{H} 2 \\
2\end{array}$ & 614 & 1845 & LG14 & I \\
\hline XsWRKY53 & EVM0011943.1 & 5.53 & $40,993.73$ & Nuclear & $\begin{array}{l}\text { WRKY } 1 \text { C2H } 2 \\
1\end{array}$ & 357 & 1074 & LG14 & $\mathrm{IIb}$ \\
\hline XsWRKY54 & EVM0002771.1 & 5.9 & $38,440.76$ & Nuclear & $\begin{array}{l}\text { WRKY } 1 \mathrm{C} 2 \mathrm{CH} \\
1\end{array}$ & 340 & 1023 & LG15 & III \\
\hline XsWRKY55 & EVM0007812.1 & 5.78 & $45,788.63$ & Nuclear & $\begin{array}{l}\text { WRKY } 1 \mathrm{C} 2 \mathrm{CH} \\
1\end{array}$ & 404 & 1215 & LG15 & III \\
\hline XsWRKY56 & EVM0011128.1 & 5.81 & $80,606.47$ & Nuclear & $\begin{array}{l}\text { WRKY } 1 \text { C2H } 2 \\
1\end{array}$ & 744 & 2235 & $\operatorname{ctg} 1408$ & IIe \\
\hline XsWRKY57 & EVM0005411.1 & 8.46 & $63,283.94$ & Nuclear & $\begin{array}{l}\text { WRKY } 2 \text { C } 2 \mathrm{H} 2 \\
2\end{array}$ & 575 & 1728 & $\operatorname{ctg} 2606$ & I \\
\hline XsWRKY58 & EVM0005607.1 & 8.72 & $51,530.29$ & Nuclear & $\begin{array}{l}\text { WRKY } 1 \text { C2H2 } \\
1\end{array}$ & 467 & 1404 & $\operatorname{ctg} 2924$ & IId \\
\hline XsWRKY59 & EVM0012687.1 & 5.83 & $53,611.21$ & Nuclear & $\begin{array}{l}\text { WRKY } 1 \mathrm{C} 2 \mathrm{CH} \\
1\end{array}$ & 492 & 1479 & $\operatorname{ctg} 3055$ & III \\
\hline
\end{tabular}

protein contains 3-12 motifs. The same group of proteins have a similar motif composition, but all XsWRKY proteins contain motifs 1 and 2, so motifs 1 and 2 that are present in WRKY are important parts of the WRKY domain. The highly similar motif 3 and motif 14 are part of the zinc finger motif domain, and with motifs 2 and 4 form the C2H2type zinc finger. Motif 9 belongs to the N-terminal WRKY domain of XsWRKY proteins. Motif 10 is unique to IIa and IIb. Motif 8 is specific to IId, and motif 20 is specific to III (Fig. 3). The motifs in different subfamilies may be related to the specific functions of the family members.

Regarding the gene structure of the $X s W R K Y$ family, all $X s W R K Y$ genes have 2 to 6 exons (Fig. 3). XsWRKY genes in the same group have a similar gene structure. For example, members of IIa and IIb except for XsWRKY19 contain only phase 0 introns, and all members of group I have $\mathrm{N}$-terminal domains that do not contain introns (Fig. 3).

\section{Distribution and synonymy analysis of $X s W R K Y$ genes in genome}

Regarding the distribution of $X s W R K Y$ genes in the yellowhorn genome, we found that in addition to XsWRKY4.1, $12.1,38.2,38.3,56,57,58,59$ (on the contig), the $X s W R K Y$ gene is unevenly distributed on 14 chromosomes except chromosome 7 (Fig. 4). Chromosome 1 contains the most $W R K Y$ genes. Although most $X s W R K Y$ genes are distributed on several chromosomes, there is no positive correlation between the number of $X s W R K Y$ genes on a chromosome and its length (Fig. 4).

To understand the expansion of the $X s W R K Y$ family, we identified two tandem repeat gene pairs, $X s W R K Y 54 / 55$ and XsWRKY19/20 (Table S3) and 23 segmental duplication events based on MCScanX for collinearity analysis of yellowhorn.

To explore the phylogenetic mechanisms of the $X s W R K Y$ family, we studied the collinear relationship between yellowhorn four dicotyledons (A. thaliana, G. max, P. trichocarpa, $M$. domestica) and two monocotyledons ( $O$. sativa and $Z$. mays) (Fig. 5). There were the most homologous gene pairs between $W R K Y$ and $X s W R K Y$ in $G$. $\max (51)$, followed by P. trichocarpa (49), A. thaliana (43), M. domestica (43), O. sativa (26) and Z. mays (22) (Table S4). The orthologous logarithms between the other six species (G. max, $P$. trichocarpa, A. thaliana, $M$. domestica, $O$. sativa, and $Z$. mays) were 151, 88, 53, 68, 43 and 36, respectively. Some $X s W R K Y$ genes have at least three related homologous gene pairs with other species (such as XsWRKY5 and XsWRKY32, $X s W R K Y 47)$. Interestingly, a collinear block in $O$. sativa and $Z$. mays with yellowhorn contained more than two $X s W R K Y$ genes, and the span of any two XsWRKY genes in the block was less than 14 genes. This phenomenon does not exist in collinear blocks in G. max, P. trichocarpa, M. domestica with yellowhorn. 


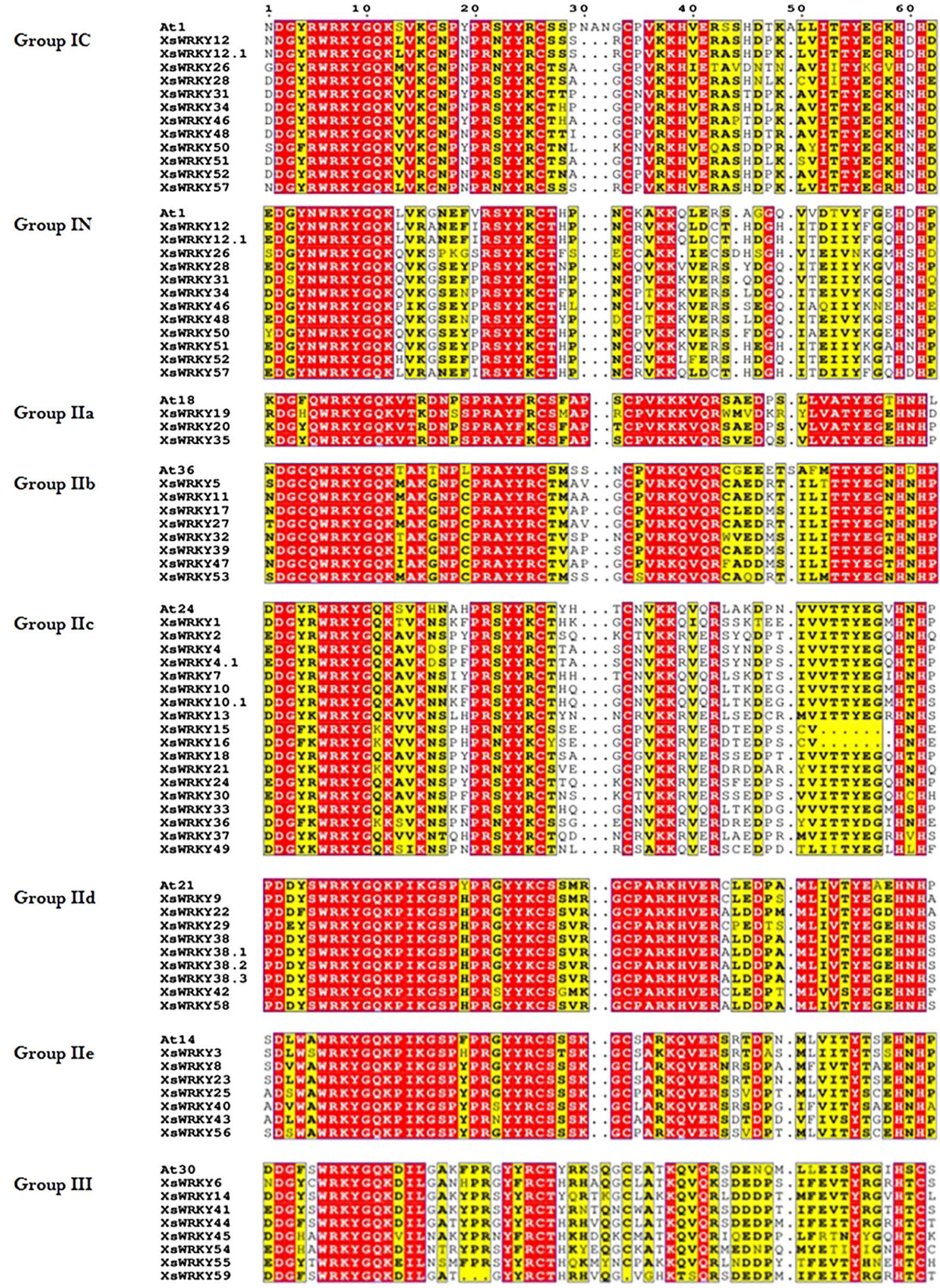

Fig. 1 Alignment of multiple XsWRKY proteins and selected AtWRKY domain amino acid sequences. Group IN and Group IC indicate the $\mathrm{N}$-terminal and C-terminal WRKY domains of group I WRKY proteins 


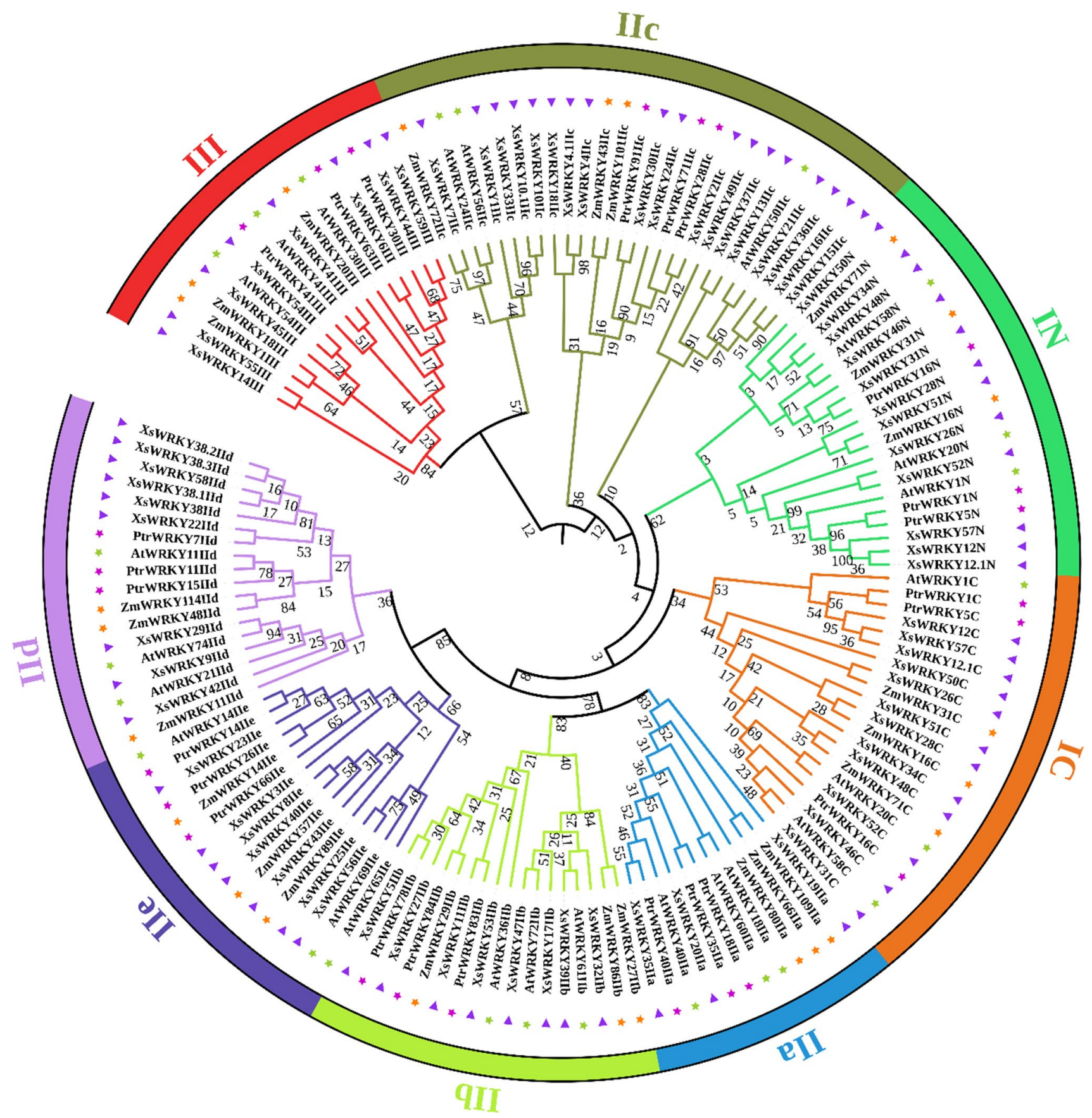

Fig. 2 Phylogenetic analysis of the WRKY domain of yellowhorn and Arabidopsis thaliana. The purple triangles represent yellowhorn; fuchsia stars represents Populus trichocarpa; orange-yellow pentagram represents Zea mays; and yellow-green stars represents $A$. thaliana. The yellowhorn WRKY protein is mainly divided into three

On the other hand, we calculated the number of $X s W R K Y$ between the two ends of XsWRKY genes in the collinear block between yellowhorn and G. $\max (40), P$. trichocarpa (32), M. domestica (21), A. thaliana (6), $O$. sativa (2) and Z. mays (0). There are some unique collinear subfamilies; group I proteins with suffix " $\mathrm{N}$ " or "C" represents an $\mathrm{N}$-terminal or C-terminal WRKY domain. The WRKY domain protein sequence was aligned with ClustalX, and the phylogenetic tree was constructed in MEGA using the maximum likelihood method. Bootstrap value is based on 1000 repetitions

gene pairs between yellowhorn and dicotyledons (A. thaliana, G. max, P. trichocarpa, and M. domestica), but there are 10 common collinear gene pairsin the yellowhorn and these 6 species. 
(a) Phylogenetic Tree

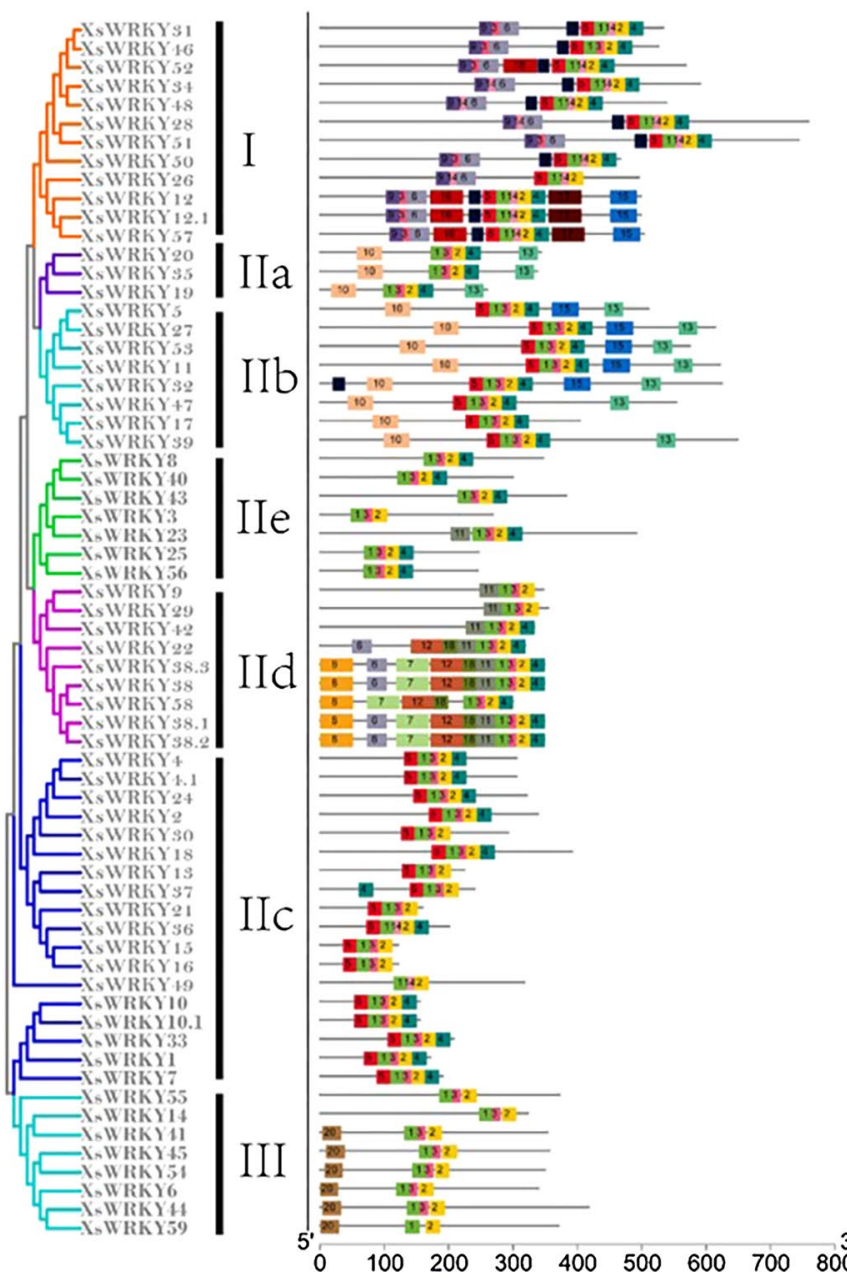

(c) Gene Structure

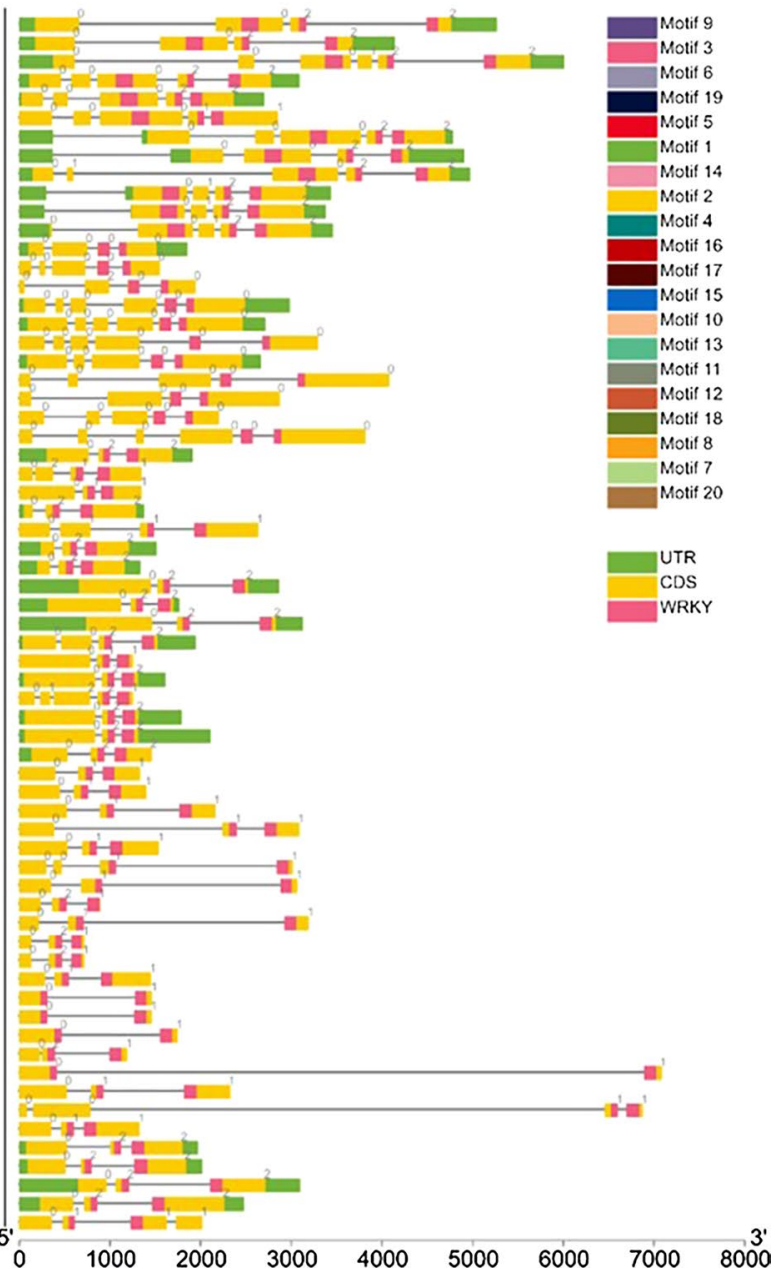

Fig. 3 Phylogenetic tree, conserved motif distribution and gene structure of the $X s W R K Y$ gene family. a Phylogenetic trees constructed using MEGA software and based on the XsWRKY gene family protein sequences mainly clustered into seven categories according to family classification and are labeled with different colors.

\section{Cis-acting regulatory element analysis of the WRKY promoter}

To identify the cis-regulatory elements in the XsWRKY promoter, we downloaded the $2-\mathrm{kb}$ sequence upstream of the initiation codons of the $X s W R K Y$ genes and analyzed them with the PLACE server (Table S5). Interestingly, numerous cis-acting elements involved in the responses to plant hormone, biotic, and abiotic stress were identified in the promoter of the $X s W R K Y$ transcription factors. According to the annotations, the elements belong to eight categories: ABA, JA, GA, SA, light, low temperature, drought, anaerobic. The elements related to light response are the most enriched, e.g., Box 4, ATCT-motif, GT1motif, GATA-motif, G-box, G-Box (Fig. 6). Other types b Conservative motifs pattern of the XsWRKY protein. Different motifs are represented by different colors and numbers (see key on right). The specific sequence information of each motif is given in Supplemental 1. c $\underline{X S W R K Y}$ gene family structure. Green: UTR, yellow: CDS, red: WRKY domain, black lines: introns

of cis-elements such as CGTCA-motif, TGACG-motif are MeJA response elements; GARE-motif, TATC-motif, P-box are gibberellin response elements; ARE is involved in anaerobic induction; LTR linked to plant response to low temperatures related; TC-rich repeats are involved in defense and stress response; the TCA-element is involved in the salicylic acid response.

\section{Expression profile of $X s W R K Y$ genes after $\mathrm{NaCl}$ or cold stress and ABA exposure}

To study the role of the $X s W R K Y$ genes in response to various environmental stresses and related signal transduction, we analyzed the transcriptional responses of the XsWRKY genes to salt, cold and ABA treatments (Table S6). After 
Fig. 4 Schematic diagram of chromosome distribution and chromosome relationship of the yellowhorn $X s W R K Y$ genes. Gray lines represent all homologous blocks in the yellowhorn genome; red lines indicate repeated pairs of $X s W R K Y$ genes; and purple represents tandem repeats. The chromosome number follows "Chr"

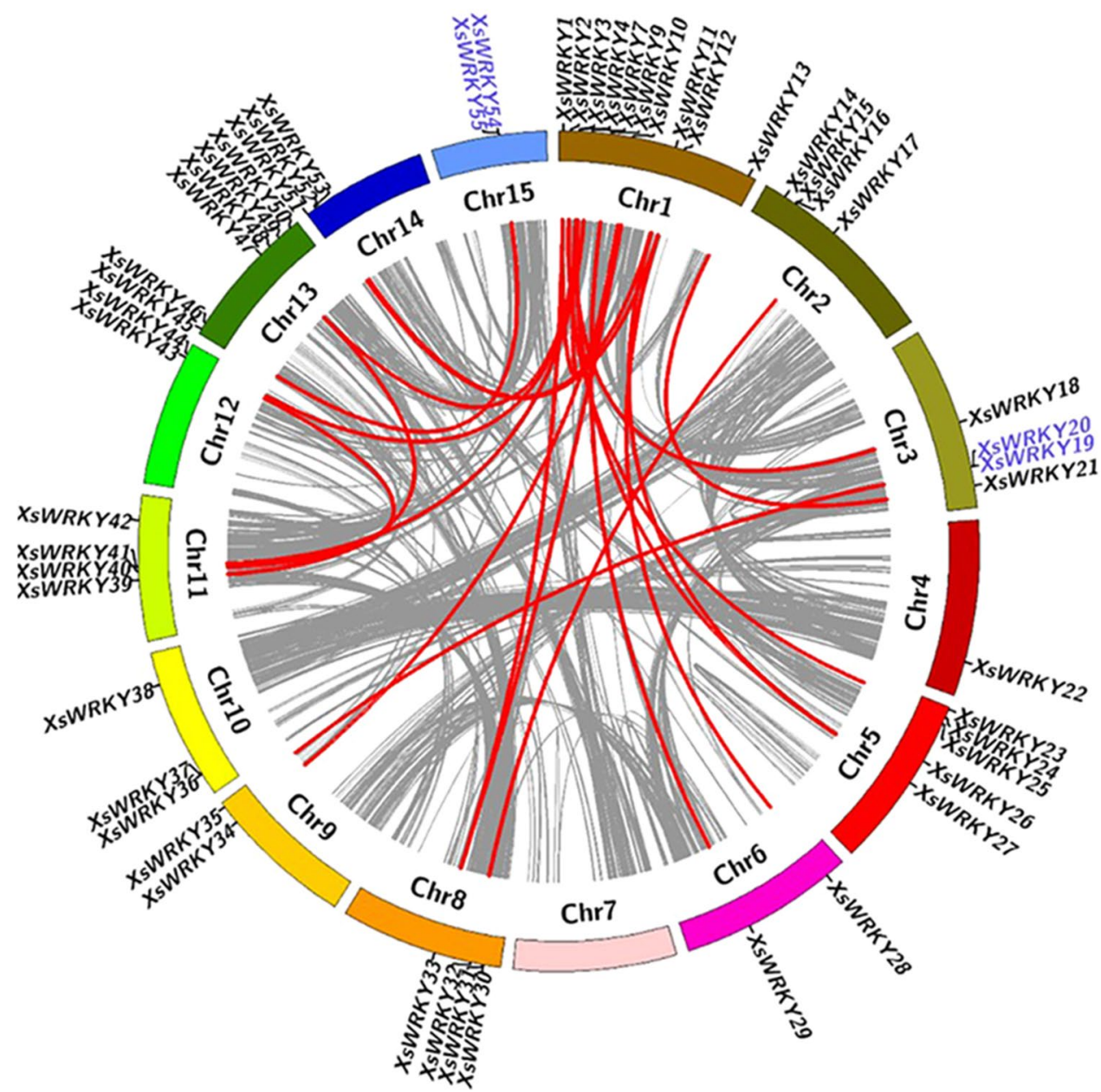

treatment with $150 \mathrm{mM} \mathrm{NaCl}$ for $24 \mathrm{~h}$, most of the differentially expressed gene (DEGs) were significantly upregulated (e.g., XsWRKY1, XsWRKY24, XsWRKY4), but XsWRKY6 was significantly downregulated after treatment for $24 \mathrm{~h}$, and significantly upregulated after $48 \mathrm{~h}$. After $48 \mathrm{~h}, X_{S} W R K Y 53$, XsWRKY24, XsWRKY27, XsWRKY4, XsWRKY5, XsWRKY1, and other genes were significantly upregulated. At $24 \mathrm{~h}$ and $48 \mathrm{~h}$ of salt treatment, 10 and 16 genes were differentially expressed genes (Fig. 7). To validate the transcriptomic data, we analyzed some $X s W R K Y$ genes by qRT-PCR and found that $X s W R K Y 22$ was induced by $\mathrm{NaCl}$ at $6 \mathrm{~h}$. The expression of $X s W R K Y 22$ peaked at $6 \mathrm{~h}$ and then slowly decreased. The expression levels of $X s W R K Y 6$ and $X s W R K Y 33$ showed a downward trend at the initial stage of induction but began to rise after $6 \mathrm{~h}$, peaked by $24 \mathrm{~h}$, then decreased by $48 \mathrm{~h}$ (Fig. 8). Other studies have shown that AtWRKY46 can regulate stomatal closure and enhance plant salt stress resistance (Ding et al. 2015). In cotton, the constitutive expression of GhWRKY17 increases plant tolerance to drought and salt stress while reducing sensitivity to ABA (Yan et al. 2014; $\mathrm{Gu}$ et al. 2018a, b). OsWRKY30 and OsWRKY72 are activated by ROS, and their overexpression makes plants more susceptible to salt stress (Yu et al. 2010; Shen et al. 2012). In conclusion, $X s W R K Y s$ are closely related to the salt stress response in yellowhorn.

Most plants native to cold areas have specific cold resistance. However, the mechanism of action of $W R K Y s$ in cold stress response is not precise. VaWRKY12 is expressed in the nucleus and cytoplasm at average temperature, but only in the nucleus after cold treatment (Zhang et al. 2019). Overexpression of VaWRKY12 enhances the cold tolerance of $A$. thaliana and grape callus and significantly increases expression of antioxidant-related genes. Overexpression of CsWRKY46 increased cold tolerance in cucumber and actively regulates cold signaling pathways in an ABA-dependent manner (Zhang et al. 2016). After $24 \mathrm{~h}$ of cold treatment in the present study, the expression of nine $X s W R K Y$ genes was significantly upregulated, for example, $X s W R K Y 4, X s W R K Y 24, X s W R K Y 35$, and XsWRKY46 (Fig. 7), but no downregulated genes were found. After $48 \mathrm{~h}$ of cold treatment, some genes were somewhat upregulated (XsWRKY4, XsWRKY46, XsWRKY40), while most of the other DEGs were significantly upregulated, and XsWRKY6 and XsWRKY54 were significantly downregulated. The 
Fig. 5 Homology analysis of the $X s W R K Y$ gene between yellowhorn and six representative plant species, Xanthoceras sorbifolium, Arabidopsis thaliana, Glycine max, Malus domestica, Oryza sativa, and Zea mays. The gray line in the background represents the collinear block in the genome of pineapple and other plants; the red line highlights the $W R K Y$ genes pair in the same line
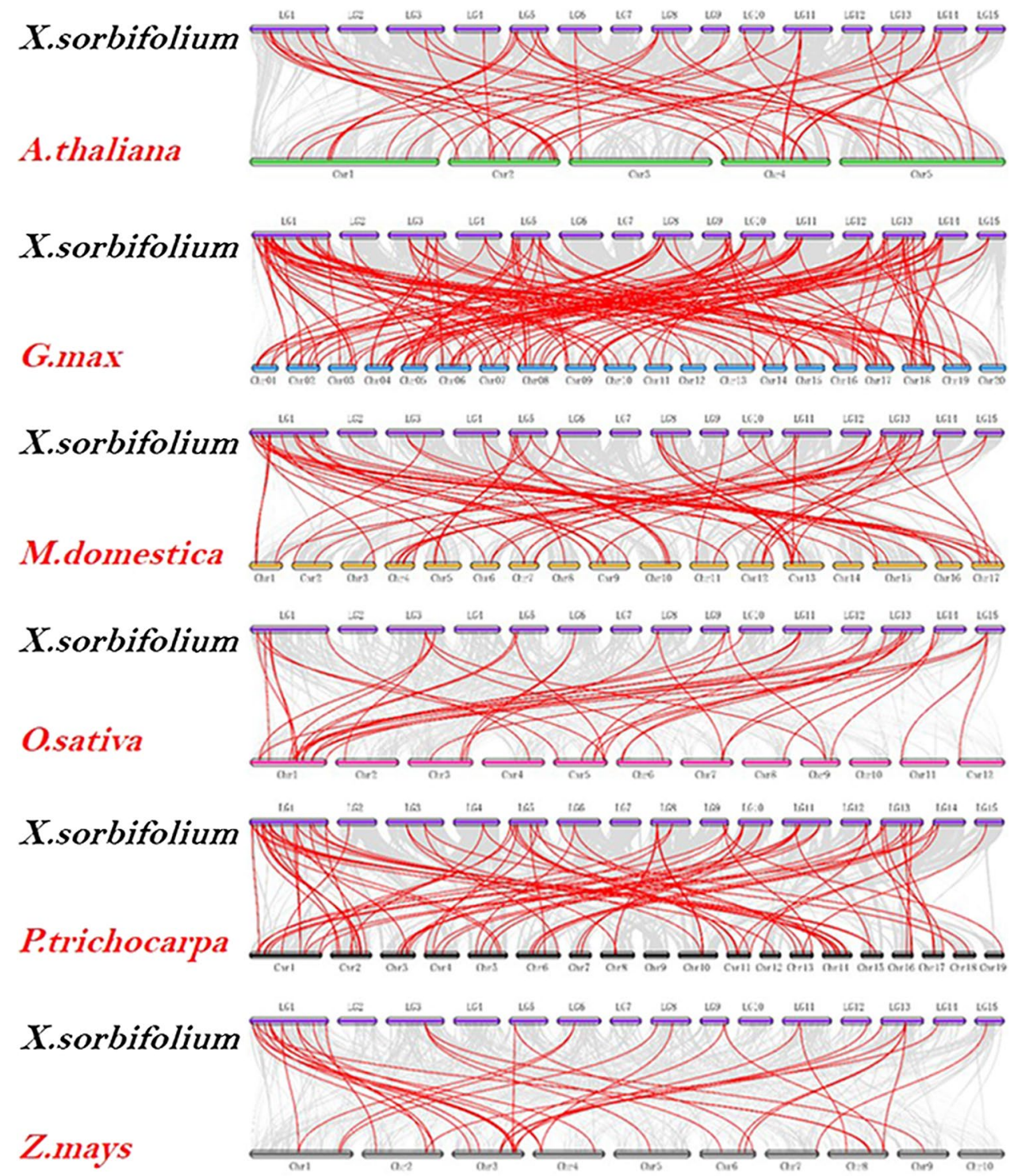

expression of XsWRKY24 as determined by qRT-PCR decreased first and then peaked at $48 \mathrm{~h}$ (Fig. 8). The expression of $X s W R K Y 34$ increased continuously after cold induction. The expression of XsWRKY6 decreased significantly after $48 \mathrm{~h}$. The expression of XsWRKY54 decreased after cold stress. As for the WRKY genes expression trend, the expression level was the highest at $6 \mathrm{~h}$ and was reduced to the lowest after $48 \mathrm{~h}$ (Fig. 7).

$\mathrm{ABA}$ is closely related to plant response to abiotic stress and plays a crucial role in response to environmental challenges. $A$. thaliana chloroplast protein ABRR interacts with WRKY transcription factors (WRKY40, WRKY18, and WRKY60) to act as ABA signals. WRKYs can also act as negative regulators. For example, WRKY40 inhibits the expression of the ABA response gene ABI5 (Shang et al. 2010). GhWRKY17 in cotton can respond to drought and salt stress through ABA signaling and regulation of cell ROS production in plants exposed to drought and salt stress (Yan et al. 2014). The expression of XsWRKY55 was significantly upregulated, and the expression of $X s W R K Y 8$ was downregulated at $24 \mathrm{~h}$ after ABA treatment. The expression of XsWRKY55 in the treated group was four times higher than in the control group. The expression of XsWRKY25 was significantly downregulated after $48 \mathrm{~h}$ of ABA treatment. qRT-PCR showed that XsWRKY54 was induced by $\mathrm{ABA}$, and its expression increased gradually in the early stage, but began to decrease after $6 \mathrm{~h}$ (Fig. 8). The results suggest that these $X s W R K Y$ genes may be involved in ABA signaling.

In conclusion, the expression pattern of $X s W R K Y$ genes under $\mathrm{NaCl}$ and cold conditions indicated that different $X s W R K Y$ genes might be involved in different stress responses. ABA treatment demonstrated that $X s W R K Y$ gene may respond to different stresses through $\mathrm{ABA}$ transduction pathway. 
Fig. 6 Phylogenetic tree and distribution of cis-regulatory elements of the $W R K Y$ genes in yellowhorn. The cis-regulatory elements were identified in $65 X s W R K Y$ genes using the PLACE server. A python script was used to extract the 2-kb upstream region from the translation initiation codon of the gene and is considered to be a proximal promoter sequence, based on the position of the cisregulator elements. a Phylogenetic tree of $W R K Y$ gene family. b Distribution of $c i s$-regulatory elements in the promoter region of the $X s W R K Y$ gene family

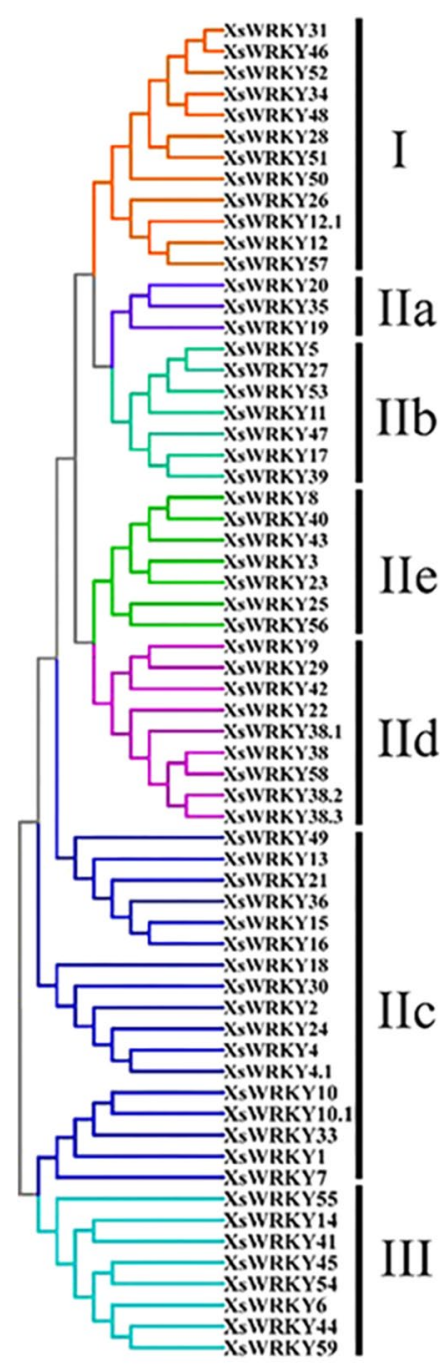

IIe

IId

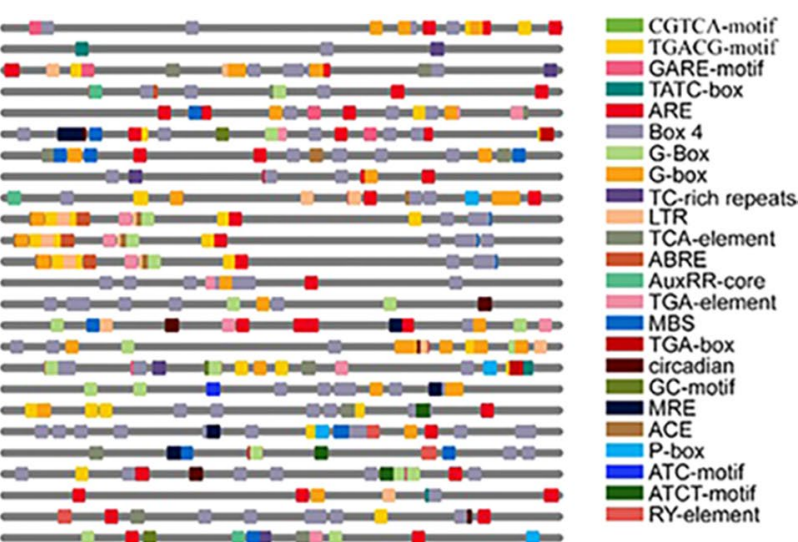

\section{Discussion}

Using the recently published yellowhorn genome (Bi et al. 2019), our laboratory found here that the genome contains 65 members of WRKY transcription factors. Based on their distribution on the chromosome, we defined them as $X s W R K Y 1$ to $X s W R K Y 59$; six sequences are redundant (XsWRKY4.1, XsWRKY10.1, XsWRKY12.1, XsWRKY38.1, XsWRKY38.2, XsWRKY38.3).

In our evaluation of the conserved domain of the XsWRKY protein, multi-sequence alignment of different subfamilies showed that the conservation of the WRKY domain differed among the subfamilies; conservation of the domain in subfamily groups IN, IIc and III was weaker than in the other groups. The WRKY domain of four members (XsWRKY15, XsWRKY16, XsWRKY21, XsWRKY36) in the IIc subfamily changed from WRKYGQK to WRKYGKK. Most XsWRKY proteins had a binding preference for the homologous homeopathic element W-box. Variation in the WRKYGQK motif in the WRKY domain may affect the interaction of the WRKY genes with downstream target genes, and this mutation also exists in other species such as pineapple (Xie et al. 2018), Caragana intermedia (Wan et al. 2018), grapes (Romero et al. 2019). So these four proteins merit further study of their function and binding specificity. Changes in the WRKY domain provide the impetus for the expansion of the WRKY gene family (Xie et al. 2018). The XsWRKY proteins in group I in yellowhorn have two WRKY domains, and groups II and III have only one, indicating that XsWRKY proteins evolved different characteristics. Subfamilies II and III apparently arose from the $\mathrm{N}$-terminal deletion in subfamily $\mathrm{I}$, and the $\mathrm{C}$-terminal domain in subfamily I members is more highly conserved than the N-terminal domain (Zhang and Wang 2005). Consistent with results of previous studies (Zhang and Wang 2005), the WRKY domains of subfamilies II and III contain introns consistent with the C-terminal WRKY domain of subfamily I. Subfamily I has the most primitive WRKY gene 
Fig. 7 Heat map of $X s W R K Y$ gene expression in response to $\mathrm{NaCl}, \mathrm{ABA}$, and $4{ }^{\circ} \mathrm{C}$ treatments and in the control group at $24 \mathrm{~h}$ and $48 \mathrm{~h}$

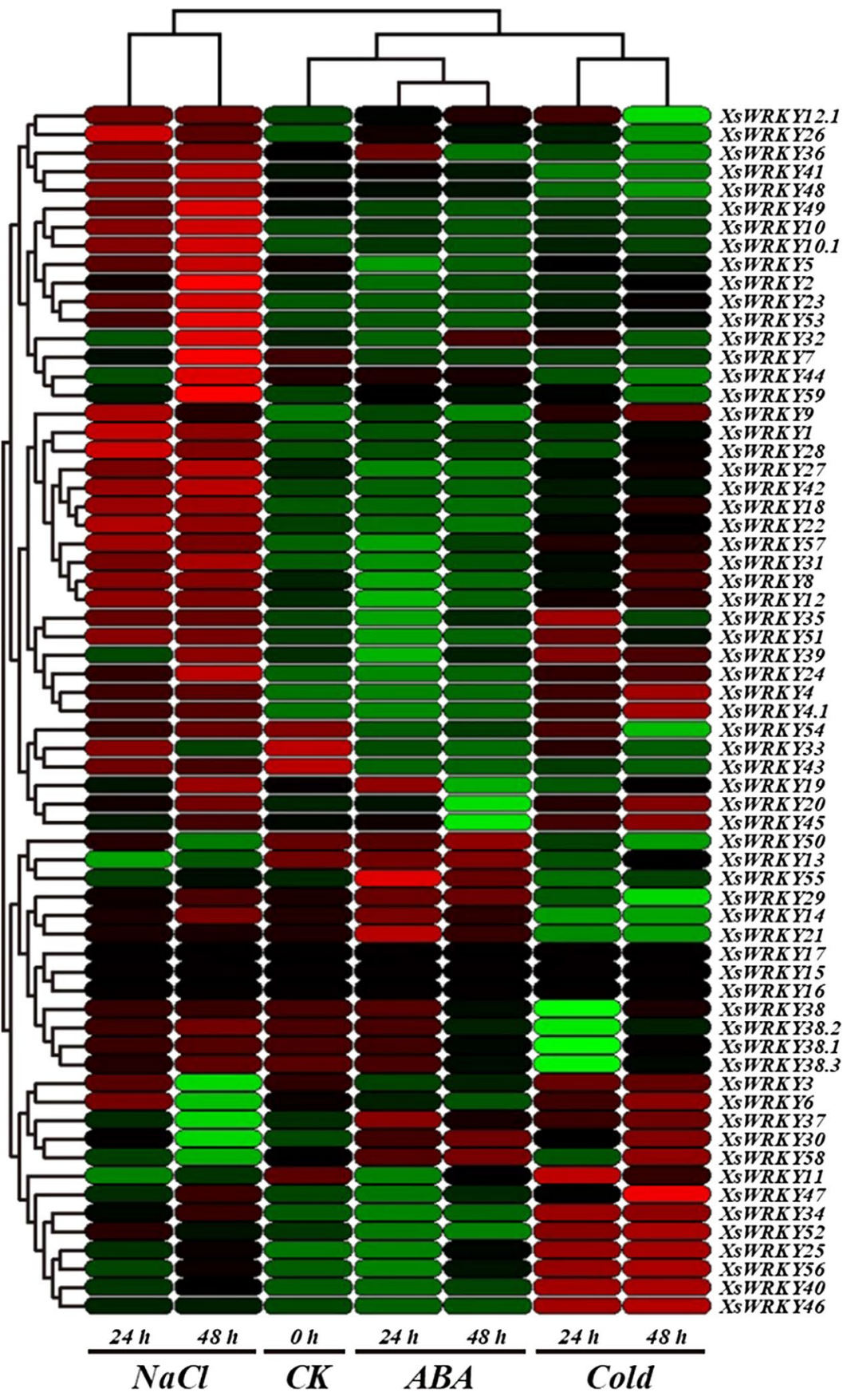

type, which transitions to phase II due to loss of differentiation of the WRKY domain. Group III may have evolved through a variation in the $\mathrm{C}$-terminal zinc finger. Each group member has the same or similar phase composition, which also implies this evolutionary relationship of the WRKY transcription factor family.

In the analysis of the $X s W R K Y$ genes of the yellowhorn genome, except for 2 tandem repeats and 23 fragment repeats, the contigs and chromosomes are highly similar; $X s W R K Y$ pairs may be potential tandem repeats or segment repeats. At the same time, 25 repeat events were identified in $33 X s W R K Y$ genes. These results indicate that the specific $X s W R K Y$ gene was generated by gene duplication and segment repeat events as the main driving force of $X s W R K Y$ evolution. At the same time, in the collinear module of yellowhorn and the other six plants analyzed, some $X S W R K Y$ gene pairs were spaced 100 or even 200 genes apart from the other species, which may be due to genetic differences between yellowhorn with other species, genomic doubling events, transposon jumping and other factors.

Compared to the genomes of dicotyledons such as M. domestica (Meng et al. 2016), A. thaliana (Dong 
Fig. 8 Expression profiles over time of the eight selected $X s W R K Y$ genes in response to various abiotic stress treatments. The data was normalized to the ACTIN gene, and vertical bars represent the standard deviation
$\mathrm{NaCl}$ WRKY6

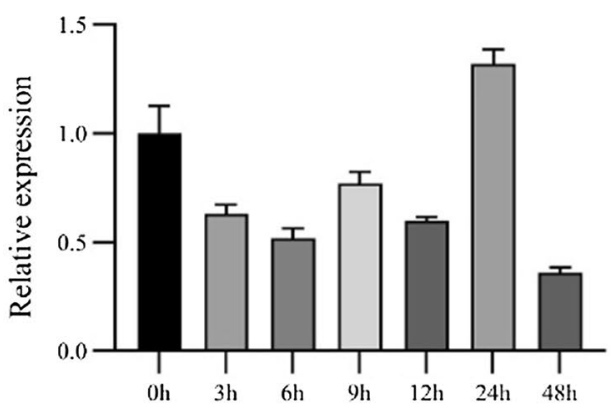

NaCI WRKY33

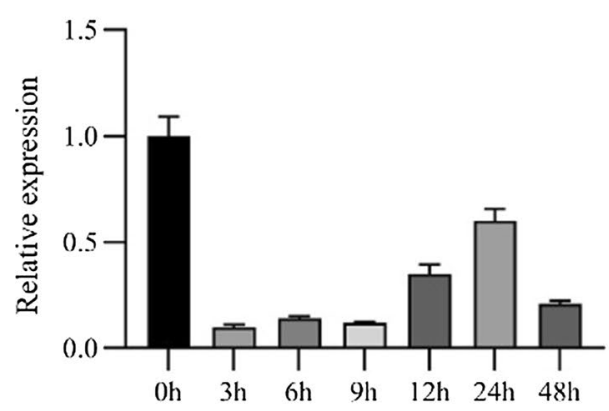

Cold WRKY24

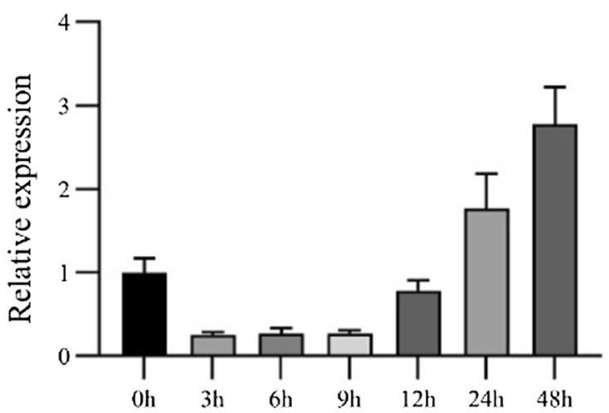

Cold WRKY54

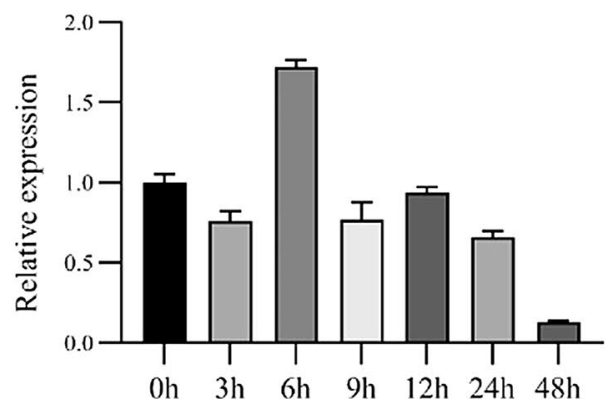

$\mathrm{NaCl} W R K Y 22$

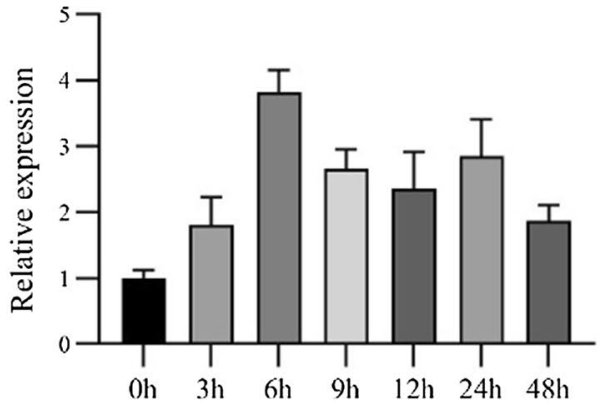

Cold WRKYG

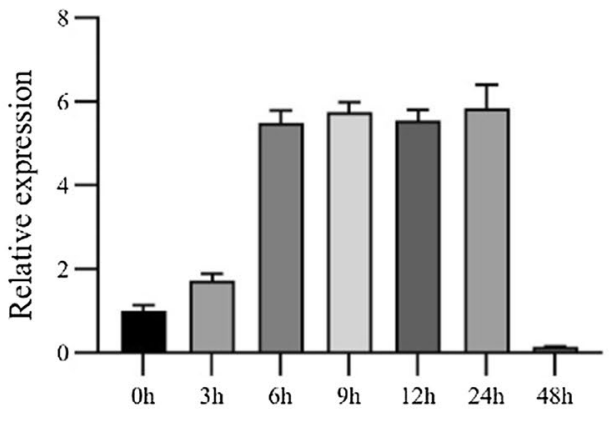

Cold WRKY34

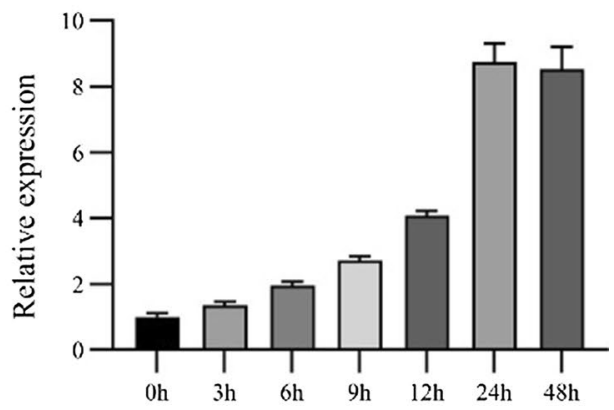

ABA WRKY 54

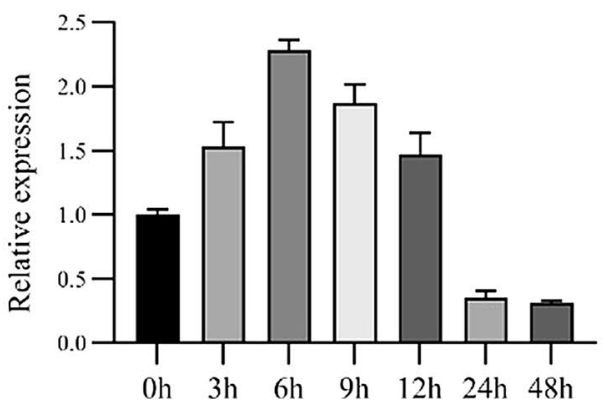

et al. 2003), G. $\max$ (Bencke-Malato et al. 2014), and $P$. trichocarpa (Tuskan et al. 2006), yellowhorn has a relatively small number of $X s W R K Y$ genes. Segmental and tandem repeat events play an important role in the expansion of the $X s W R K Y$ gene family, while genome-wide doubling events play a key role in the expansion of the gene family. Yellowhorn shares $\gamma$ whole-genome duplication events with other dicots (Murat et al. 2017), but based on the distribution of WRKY genes on the chromosomes and the collinearity analysis with other species, the lower number of $X s W R K Y$ genes in yellowhorn may be due to genomic structural variation. The collinear $X s W R K Y$ 
gene pairs between the six species and yellowhorn appear simultaneously in multiple species, which may indicate that these homologous genes may play an important role in these plants.

According to the evolutionary hypothesis of the WRKY transcription factors, the most primitive WRKY proteins only contain a WRKY domain at the C-terminal, then group I was generated by doubling, while group I lost the $\mathrm{N}$-terminal WRKY domain during evolution to produce group II (Zhang and Wang 2005). The group III WRKY gene is based on group II. Yellowhorn has fewer group III $X s W R K Y$ genes (8) than in most other dicotyledons, consistent with it having fewer members of the WRKY family. This may be related to the fact that yellowhorn is the only species of yellowhorn and has not been subjected to lineage-specific replication.

Yellowhorn is usually grown in impoverished land with scarce water, which confer resistance to various stresses including drought, cold, salt, and alkali. It is a green pioneer species. Based on the biological function of WRKY transcription factors in another species, it is reasonable to conclude that XsWRKY transcription factors are also involved in physiological processes and stress responses. Combined with public transcriptomic data and phylogenetic analysis, our studies have shown that XsWRKY proteins have a biological function similar to those of WRKY proteins in other species. For example, our transcriptomic data showed that the expression of $18 X s W R K Y$ genes was significantly induced under salt stress.

Because AtWRKY33 in A. thaliana responds to salt stress, we selected its homolog in yellowhorn, XsWRKY34, for further study. Consistently, the qRT-PCR analysis indicated that expression of XsWRKY34 was strongly induced by $150 \mathrm{mM} \mathrm{NaCl}$. The results of the qRT-PCR of XsWRKY genes showed that some $X s W R K Y$ genes were upregulated or downregulated by around $6 \mathrm{~h}$. This time point may indicate a new mechanism by which $X s W R K Y$ genes participate in conferring resistance to stress in yellowhorn. These results indicate that XsWRKY proteins play a vital role in the regulation of salt stress. Yellowhorn is mainly distributed in northern China and has cold resistance. The WRKY transcription factor is a crucial component of the cold stress regulation network. In O. sativa, OsWRKY76 (Yokotani et al. 2013) is induced by low temperature. Yellowhorn $X s W R K Y 20$ was also induced by cold stress, indicating that $X s W R K Y 20$ has a potential role in the cold response of yellowhorn (Fig. 5). Increasing studies have shown that the $W R K Y$ genes are regulated by hormones such as ABA, SA, and JA and play a crucial role in the plant hormone signal transduction network. Low temperature in the present study induced $X s W R K Y 20$ and its ortholog gene OsWRK76 in rice, indicating that they have similar functions in cold tolerance and ABA signaling network. Consistent with previous studies in other species, our results indicate that differential expression of some $X s W R K Y$ genes after various abiotic stresses and hormone treatments highlights the extensive involvement of $W R K Y$ genes in environmental adaptation.

Collectively, our findings provide new insights into the potential function of $X s W R K Y$ genes in yellowhorn. A comprehensive analysis will help select candidate WRKY genes for further functional identification and genetic improvement of forest species.

\section{Conclusion}

In this analysis of 65 full-length $W R K Y$ genes identified from yellowhorn, the XsWRKY transcription factors represented seven subfamilies with high similarity in motif composition and exon-intron structure. Homology analysis and phylogenetic comparison of WRKY genes from several different plant species provided valuable clues on duplication events during the evolution of the WRKY genes. The response of $X s W R K Y$ genes is vital to the high tolerance of yellowhorn to stresses and thus to its growth and development. These valuable insights into the function of the WRKY transcription factors highlight their potential for breeding programs to increase tolerance to poor environments.

Acknowledgements We are very grateful to Prof. Zhimin Zheng and Dr. Yi Li of the University of Southern California for their detailed comments and suggestions that improved the manuscript. We also thank the students and teachers of the Zheng Lab for their support and help with this article.

Open Access This article is licensed under a Creative Commons Attribution 4.0 International License, which permits use, sharing, adaptation, distribution and reproduction in any medium or format, as long as you give appropriate credit to the original author(s) and the source, provide a link to the Creative Commons licence, and indicate if changes were made. The images or other third party material in this article are included in the article's Creative Commons licence, unless indicated otherwise in a credit line to the material. If material is not included in the article's Creative Commons licence and your intended use is not permitted by statutory regulation or exceeds the permitted use, you will need to obtain permission directly from the copyright holder. To view a copy of this licence, visit http://creativecommons.org/licenses/by/4.0/.

\section{References}

Agarwal P, Reddy MP, Chikara J (2011) WRKY: its structure, evolutionary relationship, DNA-binding selectivity, role in stress tolerance and development of plants. Mol Biol Rep 38(6):3883-3896

Bailey TL, Boden M, Buske FA, Frith M, Grant CE, Clementi L, Ren J, Li WW, Noble WS (2009) MEME SUITE: tools for motif discovery and searching. Nucleic Acids Res 37(suppl_2):W202-W208

Bencke-Malato M, Cabreira C, Wiebke-Strohm B, Bücker-Neto L, Mancini E, Osorio MB, Homrich MS, Turchetto-Zolet AC, De Carvalho MCCG, Stolf R, Weber RLM, Westergaard G, 
Castagnaro AP, Abdelnoor RV, Marcelino-Guimarães FC, Margis-Pinheiro M, Bodanese-Zanettini MH (2014) Genome-wide annotation of the soybean WRKY family and functional characterization of genes involved in response to Phakopsora pachyrhiziinfection. BMC Plant Biol 14(1):236

Besseau S, Li J, Palva ET (2012) WRKY54 and WRKY70 co-operate as negative regulators of leaf senescence in Arabidopsis thaliana. J Exp Bot 63(7):2667-2679

Bi QX, Zhao Y, Du W, Lu Y, Gui L, Zheng ZM, Yu HY, Cui YF, Liu Z, Cui TP, Cui DS, Liu XJ, Li YC, Fan SQ, Hu XY, Fu GH, Ding J, Ruan CJ, Wang LB (2019) Pseudomolecule-level assembly of the Chinese oil tree yellowhorn (Xanthoceras sorbifolium) genome. Gigascience 8(6): giz070

Chen CJ, Chen H, He YH, Xia R (2018) TBtools, a toolkit for biologists integrating various biological data handling tools with a userfriendly interface. BioRxiv 289660

Ding ZJ, Yan JY, Li CX, Li GX, Wu YR, Zheng SJ (2015) Transcription factor WRKY46 modulates the development of Arabidopsis lateral roots in osmotic/salt stress conditions via regulation of ABA signaling and auxin homeostasis. Plant J 84(1):56-69

Dong JX, Chen CH, Chen ZX (2003) Expression profiles of the Arabidopsis WRKY gene superfamily during plant defense response. Plant Mol Biol 51(1):21-37

El-Gebali S, Mistry J, Bateman A, Eddy SR, Luciani A, Potter SC, Qureshi M, Richardson LJ, Salazar GA, Smart A (2019) The Pfam protein families database in 2019. Nucleic Acids Res 47(D1):D427-D432

Eulgem T, Rushton PJ, Robatzek S, Somssich IE (2000) The WRKY superfamily of plant transcription factors. Trends Plant Sci 5(5):199-206

Gasteiger E, Gattiker A, Hoogland C, Ivanyi I, Appel RD, Bairoch A (2003) ExPASy: the proteomics server for in-depth protein knowledge and analysis. Nucleic Acids Res 31(13):3784-3788

Göhre V, Jones AM, Sklenář J, Robatzek S, Weber AP (2012) Molecular crosstalk between PAMP-triggered immunity and photosynthesis. Mol Plant Microbe Interact 25(8):1083-1092

Gu LJ, Li LB, Wei HL, Wang HT, Su JJ, Guo YN, Yu SX (2018a) Identification of the group IIa WRKY subfamily and the functional analysis of GhWRKY17 in upland cotton (Gossypium hirsutum L.). PLOS One 13(1):e0191681

Gu LJ, Wang HT, Wei HL, Sun HR, Li LB, Chen PG, Elasad M, Su ZZ, Zhang C, Ma L, Wang CC, Yu SX (2018b) Identification, expression, and functional analysis of the group IId WRKY subfamily in upland cotton (Gossypium hirsutum L.). Front Plant Sci 9:1684

Jiang WB, Yu DQ (2009) Arabidopsis WRKY2 transcription factor mediates seed germination and postgermination arrest of development by abscisic acid. BMC Plant Biol 9(1):96

Jiang YJ, Liang G, Yang SZ, Yu DQ (2014) Arabidopsis WRKY57 functions as a node of convergence for jasmonic acid-and auxinmediated signaling in jasmonic acid-induced leaf senescence. Plant Cell 26(1):230-245

Jin JP, Tian F, Yang DC, Meng YQ, Kong L, Luo JC, Gao G (2017) PlantTFDB 4.0: toward a central hub for transcription factors and regulatory interactions in plants. Nucleic Acids Res 45(D1):D1040-D1045

Kim KC, Lai ZB, Fan BF, Chen ZX (2008) Arabidopsis WRKY38 and WRKY62 transcription factors interact with histone deacetylase 19 in basal defense. Plant Cell 20(9):2357-2371

Krzywinski M, Schein J, Birol I, Connors J, Gascoyne R, Horsman D, Jones SJ, Marra MA (2009) Circos: an information aesthetic for comparative genomics. Genome Res 19(9):1639-1645

Kumar K, Srivastava V, Purayannur S, Kaladhar VC, Cheruvu PJ, Verma PK (2016) WRKY domain-encoding genes of a crop legume chickpea (Cicer arietinum): comparative analysis with Medicago truncatula WRKY family and characterization of group-III gene (s). DNA Res 23(3):225-239
Lescot M, Déhais P, Thijs G, Marchal K, Moreau Y, Van de Peer Y, Rouzé P, Rombauts S (2002) PlantCARE, a database of plant cis-acting regulatory elements and a portal to tools for in silico analysis of promoter sequences. Nucleic Acids Res 30(1):325-327

Letunic I, Bork P (2018) 20 years of the SMART protein domain annotation resource. Nucleic Acids Res 46(D1):D493-D496

Letunic I, Bork P (2019) Interactive tree of life (iTOL) v4: recent updates and new developments. Nucleic Acids Res 47(W1):W256-W259

Love MI, Huber W, Anders S (2014) Moderated estimation of fold change and dispersion for RNA-seq data with DESeq2. Genome Biol 15(12):550

Ma JC, Lu J, Xu JM, Duan BB, He XD, Liu JQ (2015) Genome-wide identification of WRKY genes in the desert poplar Populus euphratica and adaptive evolution of the genes in response to salt stress. Evol Bioinform 11:EBO-S22067

Marchler-Bauer A, Bo Y, Han L, He J, Lanczycki CJ, Lu S, Chitsaz F, Derbyshire MK, Geer RC, Gonzales NR, Gwadz M, Hurwitz DI, Lu F, Marchler GH, Song JS, Thanki N, Wang Z, Yamashita RA, Zhang D, Zheng C, Geer LY, Bryant SH (2017) CDD/SPARCLE: functional classification of proteins via subfamily domain architectures. Nucleic Acids Res 45(D1):D200-D203

Meng D, Li YY, Bai Y, Li MJ, Cheng LL (2016) Genome-wide identification and characterization of WRKY transcriptional factor family in apple and analysis of their responses to waterlogging and drought stress. Plant Physiol Biochem 103:71-83

Miao Y, Jiang JJ, Ren YJ, Zhao ZW (2013) The single-stranded DNAbinding protein WHIRLY1 represses WRKY53 expression and delays leaf senescence in a developmental stage-dependent manner in Arabidopsis. Plant Physiol 163(2):746-756

Mistry J, Finn RD, Eddy SR, Bateman A, Punta M (2013) Challenges in homology search: HMMER3 and convergent evolution of coiled-coil regions. Nucleic Acids Res 41(12):e121-e121

Mount DW (2007) Using the basic local alignment search tool (BLAST). Cold Spring Harbor Protoc 2007(7):pdb-top17

Murat F, Armero A, Pont C, Klopp C, Salse J (2017) Reconstructing the genome of the most recent common ancestor of flowering plants. Nat Genet 49(4):490-496

Qiu YP, Yu DQ (2009) Over-expression of the stress-induced OsWRKY45 enhances disease resistance and drought tolerance in Arabidopsis. Environ Exp Bot 65(1):35-47

Robatzek S, Somssich IE (2002) Targets of AtWRKY6 regulation during plant senescence and pathogen defense. Genes Dev 16(9):1139-1149

Romero I, Alegria-Carrasco E, González de Prádena A, VazquezHernandez M, Escribano MI, Merodio C, Sanchez-Ballesta MT (2019) WRKY transcription factors in the response of table grapes (cv. Autumn Royal) to high $\mathrm{CO}_{2}$ levels and low temperature. Postharvest Biol Technol 150:42-51

Rushton PJ, Somssich IE, Ringler P, Shen QJ (2010) WRKY transcription factors. Trends Plant Sci 15(5):247-258

Rushton DL, Tripathi P, Rabara RC, Lin J, Ringler P, Boken AK, Langum TJ, Smidt L, Boomsma DD, Emme NJ, Chen X, Finer JJ, Shen QJ, Rushton PJ (2012) WRKY transcription factors: key components in abscisic acid signalling. Plant Biotechnol J 10(1):2-11

Sahraeian SME, Mohiyuddin M, Sebra R, Tilgner H, Afshar PT, Au KF, Bani AN, Gerstein MB, Wong WH, Snyder MP, Schadt E, Lam HYK (2017) Gaining comprehensive biological insight into the transcriptome by performing a broad-spectrum RNA-seq analysis. Nat Commun 8(1):1-15

Shang Y, Yan L, Liu ZQ, Cao Z, Mei C, Xin Q, Wu FQ, Wang XF, Du SY, Jiang T, Zhang XF, Zhao R, Sun HL, Liu R, Yu YT, Zhang DP (2010) The Mg-chelatase H subunit of Arabidopsis antagonizes a group of WRKY transcription repressors to relieve ABA-responsive genes of inhibition. Plant Cell 22(6):1909-1935 
Shen HS, Liu CT, Zhang Y, Meng XP, Zhou X, Chu CC, Wang XP (2012) OsWRKY30 is activated by MAP kinases to confer drought tolerance in rice. Plant Mol Biol 80(3):241-253

Sun C, Palmqvist S, Olsson H, Borén M, Ahlandsberg S, Jansson C (2003) A novel WRKY transcription factor, SUSIBA2, participates in sugar signaling in barley by binding to the sugar-responsive elements of the iso1 promoter. Plant Cell 15(9):2076-2092

Tamura K, Stecher G, Peterson D, Filipski A, Kumar S (2013) MEGA6: molecular evolutionary genetics analysis version 6.0. Mol Biol Evol 30(12):2725-2729

Tian Y, Lu XY, Peng LS, Fang J (2006) The structure and function of plant WRKY transcription factors. Yi Chuan 28(12):1607-1612

Tuskan GA, Difazio S, Jansson S, Bohlmann J, Grigoriev I, Hellsten U, Putnam N, Ralph S, Rombauts S, Salamov A, Schein J, Sterck L, Aerts A, Bhalerao RR, Bhalerao RP, Blaudez D, Boerjan W, Brun A, Brunner A, Busov V, Campbell M, Carlson J, Chalot M, Chapman J, Chen GL, Cooper D, Coutinho PM, Couturier J, Covert S, Cronk Q, Cunningham R, Davis J, Degroeve S, Déjardin A, Depamphilis C, Detter J, Dirks B, Dubchak I, Duplessis S, Ehlting J, Ellis B, Gendler K, Goodstein D, Gribskov M, Grimwood J, Groover A, Gunter L, Hamberger B, Heinze B, Helariutta Y, Henrissat B, Holligan D, Holt R, Huang W, Islam-Faridi N, Jones S, Jones-Rhoades M, Jorgensen R, Joshi C, Kangasjärvi J, Karlsson J, Kelleher C, Kirkpatrick R, Kirst M, Kohler A, Kalluri U, Larimer F, Leebens-Mack J, Leplé JC, Locascio P, Lou Y, Lucas S, Martin F, Montanini B, Napoli C, Nelson DR, Nelson C, Nieminen K, Nilsson O, Pereda V, Peter G, Philippe R, Pilate G, Poliakov A, Razumovskaya J, Richardson P, Rinaldi C, Ritland K, Rouzé P, Ryaboy D, Schmutz J, Schrader J, Segerman B, Shin H, Siddiqui A, Sterky F, Terry A, Tsai CJ, Uberbacher E, Unneberg P, Vahala J, Wall K, Wessler S, Yang G, Yin T, Douglas C, Marra M, Sandberg G, Van de Peer Y, Rokhsar D (2006) The genome of black cottonwood, Populus trichocarpa (Torr. \& Gray). Science 313(5793):1596-1604

Uji Y, Kashihara K, Kiyama H, Mochizuki S, Akimitsu K, Gomi K (2019) Jasmonic acid-induced VQ-motif-containing protein OsVQ13 influences the OsWRKY45 signaling pathway and grain size by associating with OsMPK6 in rice. Int J Mol Sci 20(12):2917

Wan YQ, Mao MZ, Wan DL, Yang Q, Yang FY, Mandlaa LGJ, Wang RG (2018) Identification of the WRKY gene family and functional analysis of two genes in Caragana intermedia. BMC Plant Biol 18(1):31

Wang DP, Zhang YB, Zhang Z, Zhu J, Yu J (2010a) KaKs_Calculator 2.0: a toolkit incorporating gamma-series methods and sliding window strategies. Genom Proteom Bioinform 8(1):77-80

Wang HZ, Avci U, Nakashima J, Hahn MG, Chen F, Dixon RA (2010b) Mutation of WRKY transcription factors initiates pith secondary wall formation and increases stem biomass in dicotyledonous plants. Proc Natl Acad Sci 107(51):22338-22343

Wang YP, Tang HB, Debarry JD, Tan X, Li JP, Wang XY, Lee TH, Jin HZ, Marler B, Guo H, Kissinger JC, Paterson AH (2012) MCScanX: a toolkit for detection and evolutionary analysis of gene synteny and collinearity. Nucleic Acids Res 40(7):e49-e49

Wang C, Deng PY, Chen LL, Wang XT, Ma H, Hu W, Yao NC, Feng Y, Chai RH, Yang GX, He GY (2013) A wheat WRKY transcription factor TaWRKY10 confers tolerance to multiple abiotic stresses in transgenic tobacco. PLOS One 8(6):e65120

Wang LN, Zhu W, Fang LC, Sun XM, Su LY, Liang ZC, Wang N, Londo JP, Li SH, Xin HP (2014) Genome-wide identification of WRKY family genes and their response to cold stress in Vitis vinifera. BMC Plant Biol 14(1):103

Wang LQ, Wang C, Qin LP, Hu P, Wang YC (2016) ThERF1 from Tamarix hispida confers decreased tolerance to oxidative and drought stresses and is regulated by a WRKY protein. J For Res 27(4):767-772
Wen F, Zhu H, Li P, Jiang M, Mao WQ, Ong C, Chu ZQ (2014) Genome-wide evolutionary characterization and expression analyses of WRKY family genes in Brachypodium distachyon. DNA Res 21(3):327-339

Xiao Y, Zhou LX, Lei XT, Cao HX, Wang Y, Dou YH, Tang WQ, Xia W (2017) Genome-wide identification of WRKY genes and their expression profiles under different abiotic stresses in Elaeis guineensis. PLOS One 12(12): 0189224

Xie Z, Zhang ZL, Zou XL, Huang J, Ruas P, Thompson D, Shen QJ (2005) Annotations and functional analyses of the rice WRKY gene superfamily reveal positive and negative regulators of abscisic acid signaling in aleurone cells. Plant Physiol 137(1):176-189

Xie T, Chen CJ, Li CH, Liu JR, Liu CY, He YH (2018) Genome-wide investigation of $W R K Y$ gene family in pineapple: evolution and expression profiles during development and stress. BMC Genom 19(1):490

Xing DH, Lai ZB, Zheng ZY, Vinod KM, Fan BF, Chen ZX (2008) Stress-and pathogen-induced Arabidopsis WRKY48 is a transcriptional activator that represses plant basal defense. Mol Plant 1(3):459-470

Yan HR, Jia HH, Chen XB, Hao LL, An HL, Guo XQ (2014) The cotton WRKY transcription factor GhWRKY17 functions in drought and salt stress in transgenic Nicotiana benthamiana through ABA signaling and the modulation of reactive oxygen species production. Plant Cell Physiol 55(12):2060-2076

Yan HF, Li MZ, Xiong YP, Wu JM, Teixeira da Silva JA, Ma GH (2019) Genome-wide characterization, expression profile analysis of WRKY family genes in Santalum album and functional identification of their role in abiotic stress. Int J Mol Sci 20(22):5676

Yokotani N, Sato Y, Tanabe S, Chujo T, Shimizu T, Okada K, Yamane H, Shimono M, Sugano S, Takatsuji H, Kaku H, Minami E, Nishizawa Y (2013) WRKY76 is a rice transcriptional repressor playing opposite roles in blast disease resistance and cold stress tolerance. J Exp Bot 64(16):5085-5097

Yu CS, Chen YC, Lu CH, Hwang JK (2006) Prediction of protein subcellular localization. Proteins Struct Funct Bioinform 64(3):643-651

Yu S, Chen LG, Zhang LP, Yu DQ (2010) Overexpression of OsWRKY72 gene interferes in the abscisic acid signal and auxin transport pathway of Arabidopsis. J Biosci 35(3):459-471

Zhang YJ, Wang LJ (2005) The WRKY transcription factor superfamily: its origin in eukaryotes and expansion in plants. BMC Evol Biol 5(1): 1

Zhang Y, Yu HJ, Yang XY, Li Q, Ling J, Wang H, Gu XF, Huang SW, Jiang WJ (2016) CsWRKY46, a WRKY transcription factor from cucumber, confers cold resistance in transgenic-plant by regulating a set of cold-stress responsive genes in an ABA-dependent manner. Plant Physiol Biochem 108:478-487

Zhang YQ, Liu ZJ, Wang XY, Wang JF, Fan K, Li ZW, Lin WX (2018) DELLA proteins negatively regulate dark-induced senescence and chlorophyll degradation in Arabidopsis through interaction with the transcription factor WRKY6. Plant Cell Rep 37(7):981-992

Zhang LL, Zhao TT, Sun XM, Wang Y, Du C, Zhu ZF, Gichuki DK, Wang QF, Li SH, Xin HP (2019) Overexpression of VaWRKY12, a transcription factor from Vitis amurensis with increased nuclear localization under low temperature, enhances cold tolerance of plants. Plant Mol Biol 100(1-2):95-110

Zhou X, Jiang Y, Yu DQ (2011) WRKY22 transcription factor mediates dark-induced leaf senescence in Arabidopsis. Mol Cells 31(4):303-313

Publisher's Note Springer Nature remains neutral with regard to jurisdictional claims in published maps and institutional affiliations. 